\title{
Climate change and anthropogenic intervention impact on the hydrologic anomalies in a semi-arid area: Lower Zab River Basin, Iraq
}

\author{
Ruqayah Mohammed ${ }^{1} \cdot$ Miklas Scholz $^{2,3,4}$ (D)
}

Received: 18 December 2017 / Accepted: 30 April 2018 / Published online: 11 May 2018

(c) The Author(s) 2018

\begin{abstract}
Climate change impact, drought phenomena and anthropogenic stress are of increasing apprehension for water resource managers and strategists, particularly in arid regions. The current study proposes a generic methodology to evaluate the potential impact of such changes at a basin scale. The Lower Zab River Basin located in the north of Iraq has been selected for illustration purposes. The method has been developed through evaluating changes during normal hydrological years to separate the effects of climate change and estimate the hydrologic abnormalities utilising Indicators of Hydrologic Alteration. The meteorological parameters were perturbed by applying adequate delta perturbation climatic scenarios. Thereafter, a calibrated rainfall-runoff model was used for streamflow simulations. Findings proved that climate change has a more extensive impact on the hydrological characteristics of the streamflow than anthropogenic intervention (i.e. the construction of a large dam in the catchment). The isolated baseflow is more sensitive to the precipitation variations than to the variations of the potential evapotranspiration. The current hydrological anomalies are expected to continue. This comprehensive basin study demonstrates how climate change impact, anthropogenic intervention as well as hydro-climatic drought and hydrological anomalies can be evaluated with a new methodology.
\end{abstract}

Keywords Climate change $\cdot$ Evapotranspiration $\cdot$ Hydro-climatic drought $\cdot$ Hydrological process $\cdot$ Indicator of Hydrologic Alteration $\cdot$ River-groundwater exchange

\section{Introduction}

Electronic supplementary material The online version of this article (https://doi.org/10.1007/s12665-018-7537-9) contains supplementary material, which is available to authorized users.

Miklas Scholz

miklas.scholz@tvrl.lth.se

1 Civil Engineering Department, Faculty of Engineering, The University of Babylon, Hilla, Iraq

2 Civil Engineering Research Group, School of Computing, Science and Engineering, The University of Salford, Newton Building, Peel Park Campus, Salford, Greater Manchester M5 4WT, UK

3 Division of Water Resources Engineering, Department of Building and Environmental Technology, Faculty of Engineering, Lund University, P.O. Box 118, 22100 Lund, Sweden

4 Department of Civil Engineering Science, School of Civil Engineering and the Built Environment, University of Johannesburg, Kingsway Campus, Aukland Park 2006, PO Box 524, Johannesburg, South Africa

\section{Background and novelty}

Alteration of seasonal river flow elements, such as minimum and maximum flows caused by climate change, drought, and anthropogenic intervention has created concern for hydrologists, owing to the consequences for riverine environments (Doll and Zhang 2010; Mittal et al. 2016; Mohammed and Scholz 2017c). In general, climate change causes a variation in the weather variables, thereby altering hydrological parameters (Mittal et al. 2016). In 2050, climate change has the prospective to intensify water resource pressures for the majority of Asian areas; arid and semi-arid regions would experience an increase in mean air temperature and a decrease in precipitation (IPCC 2014). Accordingly, the annual average streamflow is likely to decline from 10 to $30 \%$ over some arid areas at mid-latitudes. The local projections of meteorological parameters in Asia founded on a so-identified A2 drove greenhouse gas emission scenario 
by the general circulation models display that the precipitation reduction could stretch to $-40 \%$ for periods between December and February, and to $-50 \%$ for the months between June and August. However, the surge in air temperature might be in the range between +6 and $+10 \%$ during summer and winter, respectively.

Doll and Zhang (2010) argued that by the mid of the twenty-first century, it is anticipated that the basin hydrology is impacted more by climate change than anthropogenic intervention. Climate change impact is anticipated to interact with the current anthropogenic influences and thus lead to extra pressure to riverine environments (Mittal et al. 2016). To study the impact of anthropogenic perturbations and evaluate the hydrologic alterations on a basin hydrology, extensive research work has been accomplished (Yan et al. 2010; Gao et al. 2013; Sun and Feng 2013; Guo et al. 2014; Jiang et al. 2014; Duan et al. 2016; Wang et al. 2016; Mohammed and Scholz 2017b). Recent research has explored the effect of climate change on the alteration of a streamflow through utilising the Indicator for Hydrologic Alteration (IHA) (Gibson et al. 2005; Doll and Zhang 2010; Kim et al. 2011; Guo et al. 2014; Lee et al. 2014; Mittal et al. 2014; Stagl and Hattermann 2016; Mohammed and Scholz 2017b). However, most of these researchers have focused more on the ecological consequences of the stream than on the hydrological ones. For example, Stagl and Hattermann (2016) evaluated future flow alterations by means of ecologically relevant flow indicators rather than by means of hydrological relevant flow indicators. Furthermore, Stagl and Hattermann (2016) did not incorporate the meteorological and hydrological drought episodes within their methodology, and they did not evaluate how sensitive the base flow would be to climate change and river alteration, which has been considered in this research.

For climate change impact evaluation, there are three basic scenarios, which are delta perturbation (synthetic/arbitrary), analogue and Global Climate Models (GCM). To a certain degree, they reflect the history of climate construction since the construction method has established in line with the kind of data available. Delta perturbation has the simplest scenarios, whereas those from GCM are the most complex ones. For synthetic scenarios, a random alteration in a particular weather parameter is applied to an observed time series. Currently, GCM are considered the only credible tools available for simulating the physical processes that determine global climate (IPCC 2014). Researchers depend often on weather data that can be derived from GCM, which need to be converted to a local scale using statistical or dynamical (regional) down-scaling techniques. Yet, at the regional scale, they may fail to reproduce even the seasonal pattern of current climate and there are several causes of uncertainty in such climatic researches. The main reasons for uncertainties are related to the GCM and emission scenarios, as well as the variabilities that stem from a down-scaling technique (Chen et al. 2011). The GCM are data-demanding and time-consuming. Accordingly, and to avoid such difficulties and uncertainties that are linked to the GCM scenarios, recently, numerous researchers have adopted the delta perturbation (DP) scenario (e.g., Tigkas et al. 2012; Al-Faraj and Scholz 2014; Soundharajan et al. 2016; Reis et al. 2016; Mohammed and Scholz 2017c). The DP scenario is easy-to-use, provide data on a range of potential variations and can readily be applied in a reliable manner for different research areas. The scenario often demonstrates a pragmatic series of variations that are substantially reasonable, when systematic variations are applied over a very large region or when anticipated variations in parameters are not substantially consistent with each other. The DP scenario is a practical technique in identifying tipping points at which a reservoir is anticipated to fail catastrophically in supplying a pre-defined water need. The prime application of the DP scenario is in system sensitivity exploration.

\section{Aim and objectives}

The aim of this article is to propose a generic approach to evaluate the prospective effects of climate change and human-induced activities on a basin hydrology. The methodology can be used to help water resource managers to make robust and effective decisions in facing many uncertainties about the future, particularly in rather arid areas to prepare effectively for climate change. The objectives are to assess the consequences of climate change on: (1) drought events (including the correlations between meteorological and hydrological drought indices); (2) the hydrological characteristics of a basin (including sensitivity analysis of streamflow and base flow) based on the simulation of runoff when the HBV (Hydrologiska Byråns Vattenbalansavdelning, which means Water Balance Department of the Hydrological Bureau) rainfall-runoff model (Bergström 1976, 1992; Masih et al. 2010) under the Routing System (RS) MINERVE program is applied (Foehn et al. 2016); and (3) the spatiotemporal hydrologic alteration of a basin.

Subsequently, this research can be considered as a comprehensive basin study during which the impact of climate change, human intervention, and drought episodes are assessed. The research attempts to address to what extent such changes would affect a basin hydrology.

\section{Case study description}

The method was applied to the Lower (Lesser/Little) Zab River, which is an important Tigris River stream located in Erbeel Governorate, north-eastern part of Iraq. The stream and its branches are located between $36^{\circ} 50^{\prime} \mathrm{N}$ and $35^{\circ} 20^{\prime} \mathrm{N}$, and between $43^{\circ} 25^{\prime} \mathrm{E}$ and $45^{\circ} 50^{\prime} \mathrm{E}$ (Mohammed et al. 2018), 
respectively, as shown in Fig. 1. The stream has its source in the Zagros Mountains (Iran) and flows for roughly $370 \mathrm{~km}$ southeast and southwest through both the north-west of Iran and the north of Iraq. Thereafter, the Lower Zab River merges with the Tigris close to Fatha. This city is located approximately $220 \mathrm{~km}$ to the North.

The area of the Lower Zab River Basin (LZRB) is around $19,254 \mathrm{~km}^{2}$ with approximately $76 \%$ positioned in Iraq. The river is bordered by Greater Zab and Adhaim and Diyala Rivers Basins from the north and the south, respectively. The parallel Zagros mountain chains are comprised of limestone folds expanding to elevations of more than $3 \times 10^{3} \mathrm{~m}$. Water erosion has filled the Little Zab valley and the foothill zone south-west of Zagros with layers of gravel, conglomerate and sandstone. The Ranya Plain is the main valley in the LZRB, and the second largest in the Iraqi Zagros behind the Shahrazor (Saeedrashed and Guven 2013).

The Little Zab River crosses varied climatic and ecological zones. The minimum, average and maximum discharges of this river are 6, 227 and $3420 \mathrm{~m}^{3} / \mathrm{s}$ in this order (Mohammed et al. 2017). Annual precipitation near the river declines from $>1000 \mathrm{~mm}$ (Iranian Zagros) to $<200 \mathrm{~mm}$ (confluence with the Tigris River). Average air temperature recordings have about the same gradient. The valleys in the mountain are normally colder in winter compared to the foothills. However, summers in these foothills are normally warmer (NOAA 2009).

The average yearly storage of the river at Dokan and Altun Kupri-Goma is roughly 7.0 billion cubic metres (BCM) and 7.8 BCM, respectively (Mohammed et al. 2017); refer also to Fig. 1. Dokan and Dibis are the key dams that have been operated in the Iraqi part of the corresponding basin. Between 2011 and 2017, Iran has built Sardasht dam. Upstream of the Sardasht dam, Iran is planning to construct the Shivahan and Garjhal dams with the primary purpose of power generation.

The arch dam Dokan was built between 1957 and 1961 upstream from the town Dokan, having a top elevation of $116 \mathrm{~m}$ above the bed of the river $(516 \mathrm{~m})$ and $360 \mathrm{~m}$ length. The core purposes of Dokan dam are to control the streamflow, supply irrigation water, and supply hydroelectric power (Mohammed and Scholz 2017c). Dibis dam was

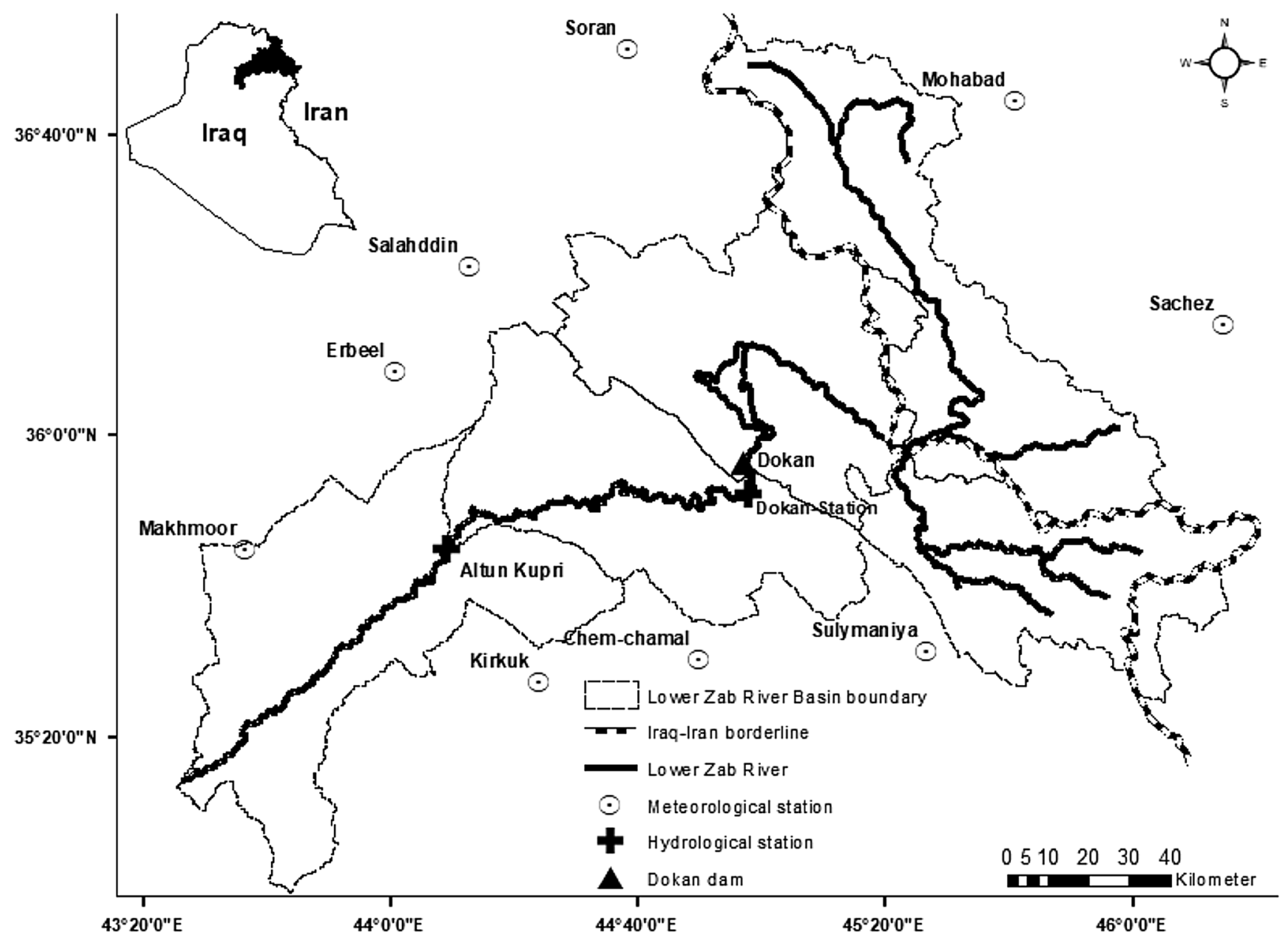

Fig. 1 Location of the meteorological and hydrological gauging stations that are distributed over the upper part of the Lower Zab River Basin 
built between 1960 and 1965, and is situated about $130 \mathrm{~km}$ upstream of the confluence with the Tigris River. The current study investigates the climate change impact linked with human-induced actions on the hydrological properties of the upper part of the LZRB with an overall drainage area of $12,095 \mathrm{~km}^{2}$ (Fig. 1) by analysing daily hydro-climatic data for the time period between 1979 and 2013. Accordingly, Dibis and Sardasht dams would not be considered in the simulation.

The LZRB has been selected as an illustrative example for a region subjected to semi-arid climate. Developments in upstream and downstream areas commonly vary, indicating different uncertainties in climate change impacts on the future availability of water. Mohammed et al. (2017) reported on severe drought impacting on the basin during the hydrologic year 2007/2008 due to about $80 \%$ reduction in the sub-basin average precipitation $\left(P_{\mathrm{av}}\right)$. Therefore, the restricted water access reduced the living standard of the population and agricultural crop production.

\section{Methods}

\section{Overview of method as well as data availability, collection and analysis}

Figure 2 shows the proposed methodological framework for evaluating the impact of climate change linked to the drought phenomena on the basin hydrology. The following data were collected: (1) daily data of precipitation as well as maximum and minimum temperature from six stations for the time-period between 1979 and 2013. These stations are distributed over the studied sub-basin with elevations ranging between 651 and $1536 \mathrm{~m}$ (Table 1; Fig. 1). (2) Daily flow rate at the Dokan hydrological station $\left(35^{\circ} 53^{\prime} 00^{\prime \prime} \mathrm{N}\right.$; $\left.44^{\circ} 58^{\prime} 00^{\prime \prime} \mathrm{E}\right)$. The drainage region for the upper part of the basin is estimated to be $12,095.64 \mathrm{~km}^{2}$ and data are available between 1931 and 2013. The Ministry of Agriculture and Water Resources (Kurdistan province, Iraq) provided the data. (3) The Iraqi boundary and the LZRB shape files have been downloaded from the Global Administrative Areas (GADM 2012) and the Global and Land Cover Facility (GLCF 2015) databases, respectively. GADM is a spatial database of the location of the world's administrative areas (or administrative boundaries), for use in GIS and similar software. GADM describes where these administrative areas are located.

ArcGIS 10.3 has been used for hydro-climatic station location projections, weighted network calculations, and the river and the basin delineations. Statistical analyses concerning the daily hydro-climatic datasets, comprising trend test, monthly and annual amounts, modifications, and the filling

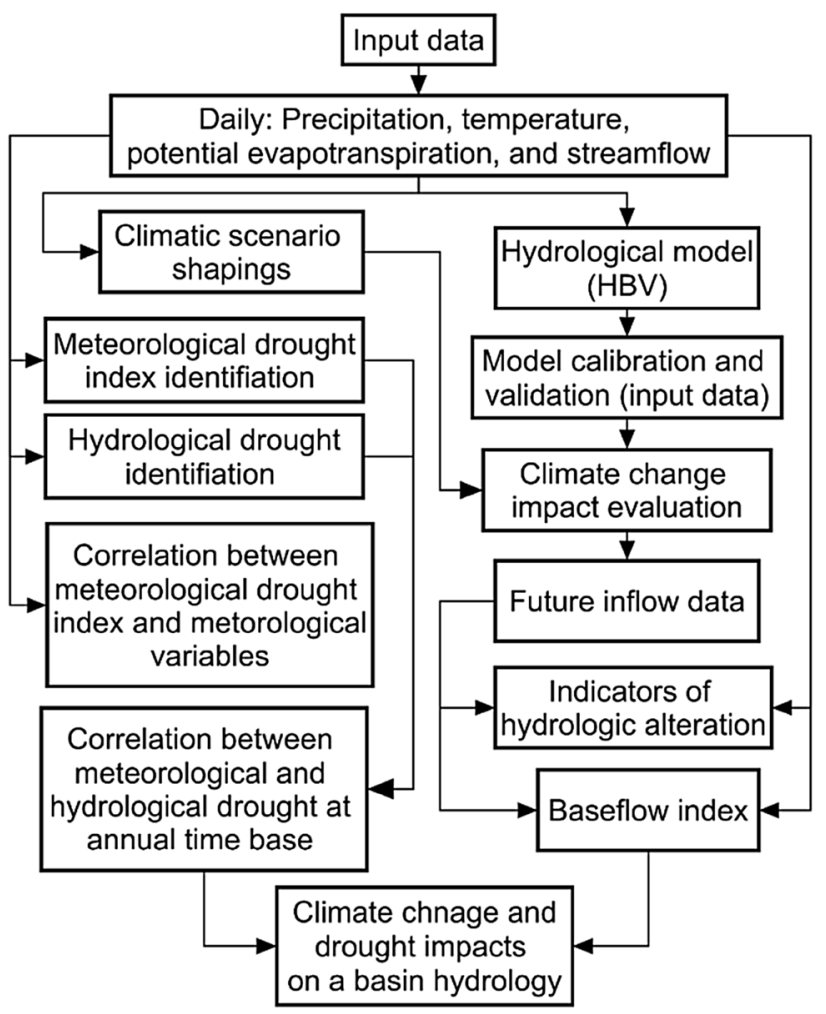

Fig. 2 Generic methodology for evaluating the impact of climate change on a basin hydrology

of data gaps were completed by the Statistical Program for Social Sciences (SPSS) 23 (ITS 2016).

The Drought Indices Calculator (DrinC) 1.5.73 has been used for the estimation of climatic drought indices [the reconnaissance drought index (RDI), the streamflow drought index (SDI) and the standardised precipitation index (SPI)]. The common features of these indices are that they require a relatively low data volume for their calculations and the outcomes can be simply understood and applied (Tigkas et al. 2012, 2015). To produce reliable results for drought characterisation, time series data of at least 30 water years should be prepared.

The standard method developed by the Food and Agriculture Organization called Penman-Monteith (Allen et al. 1998) has been used to estimate evapotranspiration through the reference evapotranspiration $\mathrm{ET}_{\mathrm{o}}(\mathrm{mm})$ computer version 3.2 (FAO 2012). The alteration of the natural flow regime has been estimated by applying the Indicators of Hydrologic Alteration software version IHA 7.1 (The Nature Conservancy 2009).

For base flow separation and flow duration curve estimation, HydroOffice 2015 (BFI+3.0 and FDC) has been used (https://hydrooffice.org/Downloads?Items=Software), by applying the methodology that was developed by Mohammed and Scholz (2016). To run the HBV rainfall-runoff 
Table 1 The distributionfree analysis for the key meteorological variables in addition to the person correlation coefficient $(r)$ for three of the widely applied drought indices over the studied basin

\begin{tabular}{llllllll}
\hline Station name & & Sulymanya & Halabcha & Sachez & Mahabad & Salahddin & Soran \\
\hline Lat $^{\mathrm{a}}\left(^{\circ}\right)$ & & 35.53 & 35.44 & 36.25 & 36.75 & 36.38 & 36.87 \\
Long $^{\mathrm{b}}\left({ }^{\circ}\right)$ & & 45.45 & 45.94 & 46.26 & 45.7 & 44.2 & 44.63 \\
$\mathrm{El}^{\mathrm{c}}(\mathrm{m})$ & & 885 & 651 & 1536 & 1356 & 1088 & 1132 \\
$a_{\mathrm{i}}{ }^{\mathrm{d}}\left(\mathrm{km}^{2}\right)$ & & 4479.57 & 735.60 & 1182.79 & 2593.31 & 1641.07 & 1463.3 \\
$P^{\mathrm{e}}(\mathrm{mm})$ & & 771.54 & 585 & 462.23 & 886.37 & 652.03 & 813.22 \\
$\mathrm{PET}_{\mathrm{o}}^{\mathrm{f}}(\mathrm{mm})$ & & 1989.42 & 979.74 & 1549.81 & 920.04 & 2058.17 & 1432.75 \\
$T_{\mathrm{m}}{ }^{\mathrm{g}}\left({ }^{\circ} \mathrm{C}\right)$ & $\mathrm{M}-\mathrm{K}^{\mathrm{k}}$ & $0.358^{* *}$ & $0.572^{* *}$ & 0.079 & $0.603^{* *}$ & $0.452^{* *}$ & $0.380^{* *}$ \\
& $p$-value & $<0.01$ & $<0.01$ & 0.500 & $<0.01$ & $<0.01$ & $<0.01$ \\
$P^{\mathrm{e}}(\mathrm{mm})$ & $\mathrm{M}-\mathrm{K}^{\mathrm{k}}$ & $-0.301^{* *}$ & $-0.522^{* *}$ & $-0.328^{* *}$ & $-0.573^{* *}$ & $-0.472^{* *}$ & $-0.426^{* *}$ \\
& $p$-value & $<0.01$ & $<0.01$ & 0.01 & $<0.01$ & $<0.01$ & $<0.01$ \\
$\mathrm{PET}^{\mathrm{f}}(\mathrm{mm})$ & $\mathrm{M}-\mathrm{K}^{\mathrm{k}}$ & 0.201 & $0.316^{* *}$ & 0.193 & $0.525^{* *}$ & 0.22 & $0.241^{*}$ \\
& $p$ value & 0.09 & $<0.01$ & 0.1 & $<0.01$ & 0.06 & 0.05 \\
$\mathrm{RDI}_{\mathrm{st}}{ }^{\mathrm{h}}$ & $\mathrm{M}-\mathrm{K}^{\mathrm{k}}$ & $-0.267^{*}$ & $-0.524^{* *}$ & $-0.308^{* *}$ & $-0.513^{* *}$ & -0.194 & $-0.563^{* *}$ \\
& $p$ value & $<0.05$ & $<0.01$ & $<0.01$ & $<0.01$ & 0.102 & $<0.01$ \\
$\mathrm{SPEI}^{\mathrm{i}}$ & $\mathrm{M}-\mathrm{K}^{\mathrm{k}}$ & -0.203 & $-0.341^{* *}$ & $-0.284^{*}$ & $-0.523^{* *}$ & $-0.281^{*}$ & $-0.595^{* *}$ \\
& $p$ value & 0.086 & $<0.01$ & 0.016 & $<0.01$ & $<0.05$ & $<0.01$ \\
SPI $^{\mathrm{j}}$ & $\mathrm{M}-\mathrm{K}^{\mathrm{k}}$ & $-0.405^{* *}$ & $-0.503^{* *}$ & $-0.333^{* *}$ & $-0.571^{* *}$ & -0.182 & $-0.573^{* *}$ \\
& $p$ value & $<0.01$ & $<0.01$ & $<0.01$ & $<0.01$ & 0.125 & $<0.01$ \\
Person $(\mathrm{r})$ correlation & $1^{1}$ & 0.89 & 0.82 & 0.85 & 0.94 & 0.95 & 0.76 \\
& $2^{\mathrm{m}}$ & 0.96 & 0.99 & 0.99 & 0.97 & 0.99 & 0.91 \\
& $3^{\mathrm{n}}$ & 0.75 & 0.82 & 0.84 & 0.93 & 0.94 & 0.70 \\
\hline
\end{tabular}

Negative (-) and positive values (+) indicate the decreasing and increasing trends, respectively

**Correlation is significant at the 0.01 level (two-tailed); and

*Correlation is significant at the 0.05 level (two-tailed)

${ }^{\text {a }}$ Latitude

${ }^{\mathrm{b}}$ Longitude

${ }^{\mathrm{c}}$ Elevation

${ }^{\mathrm{d}}$ Station area

${ }^{\mathrm{e}}$ Precipitation

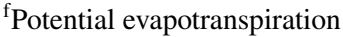

${ }^{\mathrm{g}}$ Mean air temperature

${ }^{\mathrm{h}}$ Standardised reconnaissance drought index

${ }^{i}$ Standardised precipitation evaporation index

${ }^{\mathrm{j}}$ Standardised precipitation index

${ }^{\mathrm{k}}$ Mann-Kendall distribution free test

${ }^{1} \mathrm{RDI}_{\mathrm{st}}$ vs SPEI correlation

${ }^{\mathrm{m}} \mathrm{RDI}_{\mathrm{st}}$ vs SPI correlation

${ }^{\mathrm{n}} \mathrm{SPEI}$ vs SPI correlation model, RS MINERVE 2.5 (2016; https://www.crealp.ch/ down/rsm/install2/archives.html) has been used. RS MINERVE is a free-to-download software for the simulation of surface runoff formation and propagation (Foehn et al. 2016). It models complex hydrological and hydraulic networks according to a semi-distributed conceptual scheme. RS MINERVE contains different hydrological models for rainfall-runoff in addition to $\mathrm{HBV}$.

To identify trends in the time series, a non-parametric method, the Mann-Kendall (M-K) test, has been selected as shown in Online Resource 1. Additionally, the Thiessen
Network technique has been applied to estimate the basin average precipitation $\left(P_{\mathrm{av}}\right)$, which has been outlined in Online Resource 2.

\section{Drought identification}

For identification of drought events, drought indices are seen as suitable identification techniques (Giannikopoulou et al. 2014; Mohammed and Scholz 2017a, b). The indices are important and effective components for describing climatic drought and aid decision-makers in managing its effect on 
many water use sectors, as the indices simplify difficult interrelationships between various weather parameters (Mohammed and Scholz 2017a). An extensive number of drought indices with various levels of intricacy have been used in many climatic conditions throughout the globe (Heim 2002; Agha Kouchak et al. 2015).

For its ability to be calculated for several time intervals, adjusting to several response durations of common hydrological variables to precipitation deficiencies, the World Meteorological Organization (WMO) has recommended standardised precipitation index (SPI) as a common drought index (Vicente-Serrano et al. 2015). Nevertheless, there are shortcomings linked to SPI not being able to identify drought events characterised not by a lack of precipitation, but by a greater than typical evapotranspiration. Therefore, recent drought development researchers (Sheffield et al. 2012; Vicente-Serrano et al. 2014) and drought situations under the collective impacts of climate change (e.g., Hoerling et al. 2012; Cook et al. 2014; Mohammed and Scholz 2017b) are based on drought indices that take into account potential evapotranspiration in addition to rainfall. Using such indicators, Cook et al. (2014) displayed that raised potential evapotranspiration not only increases dry weather in regions where rainfall has declined anyway, it also characterises areas as drought-prone.

Accordingly, the literature has highlighted the advantages and the drawbacks of many meteorological drought indices. Thus, and to select the most appropriate one for semi-arid and arid areas, it is interesting to compare the results of three of the widely used meteorological drought indices: SPI, the standardised reconnaissance drought index $\left(\mathrm{RDI}_{\mathrm{st}}\right)$, and the standardised precipitation evapotranspiration index (SPEI). In addition, the correlation between meteorological and hydrological drought indices should be specified. The Online Resource 3 includes the mathematical details for the selected drought indices.

\section{Runoff simulation and climate change scenarios}

The HBV rainfall-runoff model (Bergström 1976, 1992; Masih et al. 2010) has been applied for streamflow simulation. The overall water balance can be defined by Eq. (1).

$P-\mathrm{PET}-R=\frac{d}{d t}(\mathrm{SP}+\mathrm{SM}+\mathrm{UZ}+\mathrm{LZ}+$ lake $)$

where $\mathrm{P}$ is precipitation, PET is the potential evapotranspiration, $\mathrm{R}$ is the surface runoff, $\mathrm{SP}$ is the snow pack, $\mathrm{SM}$ is the soil moisture, $\mathrm{UZ}$ is the upper groundwater zone, $\mathrm{LZ}$ is the lower groundwater zone, and lake is the lake volume.

The HBV model has been used in more than 40 countries over the world with such different weather conditions such as Colombia, India, Zimbabwe, and Sweden. This conceptual semi-distributed model estimating daily streamflow is based on corresponding daily precipitation, temperature, and potential evapotranspiration. The model has been both calibrated and subsequently validated based on the time-period from 1988 to 2000 .

Thirty-five water years (1979-2013) were applied to calculate the $\mathrm{RDI}_{\mathrm{st}}$ amounts, to identify the time-period during which not one extreme $\mathrm{RDI}_{\mathrm{st}}$ number is recorded, and when the mean $\mathrm{RDI}_{\mathrm{st}}$ amount is near zero, which represent the normal climatic condition.

In anticipation of the influence of climate change on the hydrological properties of the basin, many climatic scenarios that integrate changes in weather data (precipitation and potential evapotranspiration) are formulated by implementing delta perturbation scenarios by which the historical climatic variables (mean air temperature and/or precipitation) are perturbed incrementally (and rationally) through arbitrary amounts [Eq. (2)] such as steps of $2 \%$ within the range from 0 to $-40 \%$ for precipitation and from 0 to $+30 \%$ for potential evapotranspiration. The range of the scenarios should be adequately wide to comprise the expected changes of the weather parameters, which have been projected.

$\operatorname{AMV}_{t}(\mathrm{~mm})=\mathrm{OMV}_{t}(\mathrm{~mm}) \mp \mathrm{RA}(\%) \times \mathrm{OMV}_{t}(\mathrm{~mm})$

where $\mathrm{AMV}_{t}$ is the anticipated meteorological variable $(\mathrm{mm})$ at a specific time step $t, \mathrm{OMV}_{t}$ is the observed meteorological variable ( $\mathrm{mm}$ ) at a specific time step $t$ and RA is the added or subtracted ratio (\%).

In this way, all potential arrangements (around 336 scenarios) comprising all options of precipitation and potential evapotranspiration variations, which lie within the considered ranges, have been taken into consideration. Online Resources 4 lists some of the considered delta perturbation climatic situations. These developments comprise all potential basin-wide climate change predictions, in addition to a wide range of drought severity situations.

For assessing the performance of the HBV model, many statistical criteria can be applied. Online Resource 5 provides a corresponding overview.

\section{Indicator of Hydrologic Alteration}

The Nature Conservancy (2009) has developed a simple tool for natural and changed hydrologic system estimations, which is the Indicator for Hydrologic Alteration (IHA). The IHA uses daily streamflow data to calculate 76 parameters, which are divided into 33 within IHA and 34 within the Environmental Flow Component (EFC). The 33 IHA parameters are classified into five groups addressing the magnitude, timing, frequency, duration, and rate of change (Richter et al. 1997, 1998; Jiang et al. 2014), which are described in Online Resource 6. 
To investigate the alteration between two periods, the IHA program supports customers to apply the Range of Variability Approach (RVA) defined by Richter et al. (1997) in Online Resource 6. The RVA utilises the pre-development normal deviation of IHA parameters for describing to which extent the normal streamflow has been changed. The RVA analysis creates a series of hydrologic alteration factors, which quantify the alteration level of the 33 IHA variables. The RVA test is only obtainable for IHA variables, and results in a programmed delineation of three classes of the same number of entries: the low class covers all values less than or equal to the $33 \mathrm{rd}$ percentile; the middle class covers all numbers that are within the range of the 34th-67th percentiles, and the high class covers all entries larger than the 67 th percentile.

The software subsequently calculates the anticipated rate for the post-impact values of the IHA parameters falling within each class. This anticipated rate is equivalent to the amount number in the class through the pre-alteration time-period, which is multiplied by the percentage of postalteration to pre-alteration water years. Last, the hydrologic alteration factor is computed for all the three classes, which is shown by Eq. (3).

LZR flow lteration $\%=\frac{\mathrm{LZR}_{\text {affected flow }}-\mathrm{LZR}_{\text {baseline }}}{\mathrm{LZR}_{\text {baseline }}} \times 100$

where $\mathrm{LZR}_{\text {affected }}$ and $\mathrm{LZR}_{\text {baseline }}\left(\mathrm{m}^{3} / \mathrm{s}\right)$ are the median annually affected flow rate and long-term median yearly baseline flows for the totally unchanged circumstance, respectively.

The hydrologic alteration is equivalent to zero, if the recorded frequency of post-alteration yearly values falling within the RVA objective range is equal to the anticipated one. A positive variation refers to values of annual parameters falling within the RVA objective window more frequently than anticipated, whereas negative values indicate that the data fall inside the RVA objective range less frequently than anticipated.

Furthermore, this study also highlights the scorecard table (Online Resource 6), which involves a variety of statistics such as the annual coefficient of variation $\left(C_{\mathrm{v}}\right)$, flow predictability, consistency (predictability), percentage of flood within a 60-day period, length of flood-free season, coefficient of dispersion (CD), significance count, deviation factor for the median and coefficient of distribution.

\section{Results and discussion}

\section{Trend analysis and drought identification}

The Mann-Kendall (M-K) analysis shows that there is a considerably positive trend in the yearly mean temperature $\left(T_{\mathrm{m}}\right)$ at about $84 \%(p<0.01)$ of the considered sites (Table 1). The significant warming trends in the yearly $T_{\mathrm{m}}$ varied from 0.37 to $1.91{ }^{\circ} \mathrm{C}$ within a decade. The observed trend of a rise in average air temperature over the previous five decades caused a significant $(p<0.05)$ increase in the potential evapotranspiration for LZRB (Table 1). The increase in the potential evapotranspiration rate was $39 \mathrm{~mm}$ per decade (average of about $1065 \mathrm{~mm}$ ). The annual precipitation was reduced, and the annual mean temperature rose (Table 1). The weather data analysis outcomes prove that the climate of the study area is getting warmer and drier as a consequence of climate change over the past 30 years. The obtained outcomes of LZRB are generally in agreement with earlier research, for example, by Fadhil (2011) and Robaa and AL-Barazanji (2013).

Table 1 also summarises the $\mathrm{M}-\mathrm{K}$ analysis results and the person correlation coefficient $r$ for the annual values of SPI, RDI ${ }_{\mathrm{s}}$, and SPEI. Substantial tendencies for the drought indices were witnessed at $1 \%$ significance level. Additionally, Table 1 illustrates a comparison between the indices, which shows that the three indicators were adjacent to each other, but the correlation between $\mathrm{RDI}_{\mathrm{st}}$ and SPI was the best, and the RDI $\mathrm{st}_{\text {st }}$ and SPEI correlation was better than between SPEI and SPI. Accordingly, $\mathrm{RDI}_{\mathrm{st}}$ can be selected for further drought analysis within the studied region.

To demonstrate the relationships between meteorological and hydrological drought, the calculations for the annual reference period for SPI, RDI ${ }_{\text {st }}$ and SPEI have been performed (Online Resource 7). These data were then correlated with the annual SDI values. Online Resource 7 reveals linear relationships between the considered drought indices for the period from $1979 / 1980$ to $2013 / 2014$. It can be concluded that the equations show better fits between SDI and RDI ${ }_{\text {st }}$ than between SDI and SPEI as indicated by higher correlation coefficients. Accordingly, $\mathrm{RDI}_{\mathrm{st}}$ is recommended for further drought analysis within the region. Even though this method involves substantial uncertainty, it is useful since the proactive processes to moderate consequences of drought are based on the classification of the predicted drought and not on the total value of SDI (Table 2).

Table 3 presents a summary of the impact of climate change, which is characterised by precipitation reduction and potential evapotranspiration increase concerning the average annual hydrological characteristics of the LZRB. 
Table 2 Meteorological and hydrological drought classifications based on the standardised reconnaissance drought index $\left(\mathrm{RDI}_{\mathrm{st}}\right)$, the standardised precipitation index (SPI), and the stream flow index (SDI) values, respectively

\begin{tabular}{llllll}
\hline No. & RDI $_{\text {st }}$ and SPI range & Drought classes & No. & SDI range & Drought classes \\
\hline 1 & $\geq 2.0$ & Extremely wet & 0 & $\geq 0.0$ & Non- \\
2 & 1.99 to 1.50 & Very wet & 1 & -0.99 to 0.01 & Mild \\
3 & 1.49 to 1.00 & Moderately wet & 2 & -1.49 to -1.00 & Moderately wet \\
4 & 0.99 to 0.00 & Normal & 3 & -1.99 to -1.49 & Severe \\
5 & 0.00 to -0.99 & Near normal & 4 & $<-2$ & Extreme \\
6 & -1 to -1.49 & Moderately dry & & & \\
7 & -1.5 to -1.99 & Severely dry & & & \\
8 & $\leq-2.0$ & Extremely dry & & &
\end{tabular}

It is important to note that the streamflow is usually high over the baseline scenario compared to the future flow values that were predicted by any of the selected climate change scenarios. Typically, the rate of the annual runoff departure depends mainly on the level of shift in the yearly precipitation and potential evapotranspiration associated with the long-term annual mean values. For example, the flow may decline from $2305 \mathrm{~m}^{3} / \mathrm{s}$ for the baseline period to $1623 \mathrm{~m}^{3} / \mathrm{s}$, because of $10 \%$ precipitation reduction and no potential evapotranspiration increase, which leads to a significant $(p<0.01)$ increase in the anticipated hydrological drought.

To assess the occurrence of meteorological drought events for the studied geographical area, the $\mathrm{RDI}_{\mathrm{st}}$ (Vicente-Serrano et al. 2010; Mohammed and Scholz 2017a) was estimated utilising the existing precipitation data and the predicted potential evapotranspiration. Figure $3 \mathrm{a}, \mathrm{b}$ presents the indices calculated for the years between 1979 and 2014 incorporating the longterm average sub-basin precipitation $\left(P_{\mathrm{av}}\right)$ and potential evapotranspiration $\left(\mathrm{PET}_{\mathrm{av}}\right)$, respectively. A non-regular cyclical configuration of drought and rainy times was detected. Droughts on a cyclical base were identified for 5 years over the considered dataset; mostly for 1998/1999, 1999/2000, 2000/2001, 2007/2008, and 2008/2009 (for example, corresponding $\mathrm{RDI}_{\mathrm{st}}$ mean values were -1.76 , $-1.39,-1.60,-2.68$, and -1.70 in this order). Similar findings were reported, previously (Fadhil 2011; UNESCO 2014; Mohammed et al. 2017). In general, droughts typically occur at the start of the rainy period, which is reflected by either a decrease in precipitation coupled with a potential evapotranspiration increase or a postponement in precipitation incidents. Based on the $\mathrm{RDI}_{\mathrm{st}}$ assessment, the severity of the basin drought got dramatically worse over the past 12 years. In particular, during the years from 1998 to 2011, the drought severity increased as the number of months with longer times of precipitation shortages and potential evapotranspiration growths increased.

\section{Streamflow simulation}

To specify the normal climatic condition, 35 water years (1979-2013) were used (Fig. 4). Subsequently, a period of 12 water years (1988/1989-1999/2000) was applied for the calibration of the HBV model and climate change scenarios, whereas the range between $1979 / 1980$ and $1986 / 1987$ was the validation period.

The statistical criteria RMSE, IoA, r, and MAE of the considered rainfall-runoff model (HBV) were 0.73, 0.99, 0.93 , and 0.65 and $0.68,0.99,0.84$, and 0.60 during the calibration and validation periods, respectively. This outcome shows promising modelling results, which suggest running further artificial climate scenarios and predicting the relative change (\%) in the mean yearly LZRB flow compared to the natural climatic environments. Figure 5 shows the simulated against the observed runoff for the representative case study.

\section{Dam building impact}

The IHA can be used to determine how the flow regime will be affected by abrupt alteration due to river regulation (i.e. dam building in this case study). This can be achieved through estimating the hydrological parameters for the predamming and the post-damming time durations. However, for hydrologic regimes that have experienced a long-term accumulation of anthropogenic interventions, the IHA can calculate and draw linear regressions to assess the trend.

The yearly change ratio of the altered period (post-damming) relative to the lasting median annual flow rate for the unaltered timespan (pre-damming) was computed based on Eq. (3). Figure $3 \mathrm{c}$ indicates the alterations of the median yearly flow for the post-damming scenario according to the long-term pre-damming median yearly flowrate.

Figure 6 shows a comparison of monthly percentiles between the pre-damming and the post-damming periods for the (a) 10th, (b) 25th, (c) 50th, (d) 75th, and (e) 90th percentiles. 
Table 3 Summary of the average annual hydrological characteristics of the Lower Zab River Basin in addition to the streamflow drought index (SDI) significant test under the collective impacts of precipitation $(P)$ reduction and potential evapotranspiration (PET) increase

\begin{tabular}{|c|c|c|c|c|c|c|}
\hline Considered time & \multicolumn{3}{|c|}{ Hydro-climatic parameters } & & & Values \\
\hline \multirow[t]{5}{*}{ Baseline } & \multicolumn{3}{|c|}{$P(\mathrm{~mm})$} & & & 844.08 \\
\hline & \multirow{2}{*}{\multicolumn{3}{|c|}{ PET (mm) }} & & & 1009 \\
\hline & & & & & & 2305 \\
\hline & \multicolumn{3}{|c|}{$\operatorname{Inflow}_{\text {wet }}\left(\mathrm{m}^{3} / \mathrm{s}\right)$} & & & 2249 \\
\hline & \multicolumn{3}{|c|}{$\operatorname{Inflow}_{\text {dry }}\left(\mathrm{m}^{3} / \mathrm{s}\right)$} & & & 331 \\
\hline \multirow[t]{2}{*}{$\%$ reduction of $P$} & \multicolumn{2}{|c|}{ Hydro-climatic parameters } & \multicolumn{3}{|c|}{$\%$ increase of PET } & \\
\hline & & & 0 & 10 & 20 & 30 \\
\hline \multirow[t]{7}{*}{0} & $P(\mathrm{~mm})$ & & 844.08 & & & \\
\hline & PET (mm) & & 1009 & 1110 & 1211 & 1312 \\
\hline & Inflow $\left(\mathrm{m}^{3} / \mathrm{s}\right)$ & & 1884 & 1832 & 1783 & 1737 \\
\hline & $\operatorname{Infow}_{\text {wet }}\left(\mathrm{m}^{3} / \mathrm{s}\right)$ & & 1596 & 1550 & 1509 & 1470 \\
\hline & $\operatorname{Inflow}_{\text {dry }}\left(\mathrm{m}^{3} / \mathrm{s}\right)$ & & 289 & 283 & 274 & 267 \\
\hline & SDI & $\mathrm{M}-\mathrm{K}^{\mathrm{a}}$ & $0.718^{* *}$ & $0.718^{* *}$ & $0.687^{* * *}$ & $0.687^{*}$ \\
\hline & & $p$ value & $<0.01$ & $<0.01$ & $<0.01$ & $<0.01$ \\
\hline \multirow[t]{6}{*}{10} & $P(\mathrm{~mm})$ & & 759.69 & & & \\
\hline & Inflow $\left(\mathrm{m}^{3} / \mathrm{s}\right)$ & & 1623 & 1576 & 1531 & 1490 \\
\hline & $\operatorname{Infow}_{\text {wet }}\left(\mathrm{m}^{3} / \mathrm{s}\right)$ & & 1371 & 1331 & 1294 & 1260 \\
\hline & $\operatorname{Inflow}_{\text {dry }}\left(\mathrm{m}^{3} / \mathrm{s}\right)$ & & 252 & 244 & 237 & 230 \\
\hline & SDI & $\mathrm{M}-\mathrm{K}^{\mathrm{a}}$ & $0.718^{* *}$ & $0.687^{* *}$ & $0.687^{* *}$ & $0.687^{* *}$ \\
\hline & & $p$ value & $<0.01$ & $<0.01$ & $<0.01$ & $<0.01$ \\
\hline \multirow[t]{6}{*}{20} & $P(\mathrm{~mm})$ & & 675.26 & & & \\
\hline & Inflow $\left(\mathrm{m}^{3} / \mathrm{s}\right)$ & & 1369 & 1327 & 1287 & 1251 \\
\hline & Inflow $_{\text {wet }}\left(\mathrm{m}^{3} / \mathrm{s}\right)$ & & 1155 & 1120 & 1087 & 1057 \\
\hline & $\operatorname{Inflow}_{\text {dry }}\left(\mathrm{m}^{3} / \mathrm{s}\right)$ & & 214 & 207 & 200 & 194 \\
\hline & SDI & $\mathrm{M}-\mathrm{K}^{\mathrm{a}}$ & $0.708^{* *}$ & $0.687^{* *}$ & $0.687^{* *}$ & $0.687^{* *}$ \\
\hline & & $p$ value & 0.002 & 0.002 & 0.002 & 0.002 \\
\hline \multirow[t]{6}{*}{30} & $P(\mathrm{~mm})$ & & 590.88 & & & \\
\hline & Inflow $\left(\mathrm{m}^{3} / \mathrm{s}\right)$ & & 1123 & 1087 & 1053 & 1021 \\
\hline & $\operatorname{Inflow}_{\text {wet }}\left(\mathrm{m}^{3} / \mathrm{s}\right)$ & & 946 & 916 & 888 & 862 \\
\hline & $\operatorname{Inflow}_{\text {dry }}\left(\mathrm{m}^{3} / \mathrm{s}\right)$ & & 177 & 171 & 165 & 160 \\
\hline & SDI & $\mathrm{M}-\mathrm{K}^{\mathrm{a}}$ & $0.687^{* *}$ & $0.687^{* *}$ & $0.687^{* *}$ & $0.692^{* *}$ \\
\hline & & $p$ value & $<0.01$ & $<0.01$ & $<0.01$ & $<0.01$ \\
\hline \multirow[t]{6}{*}{40} & $P(\mathrm{~mm})$ & & 506.44 & & & \\
\hline & Inflow $\left(\mathrm{m}^{3} / \mathrm{s}\right)$ & & 889 & 858 & 830 & 804 \\
\hline & $\operatorname{Inflow}_{\text {wet }}\left(\mathrm{m}^{3} / \mathrm{s}\right)$ & & 748 & 722 & 699 & 677 \\
\hline & $\operatorname{Inflow}_{\text {dry }}\left(\mathrm{m}^{3} / \mathrm{s}\right)$ & & 141 & 136 & 131 & 126 \\
\hline & SDI & $\mathrm{M}-\mathrm{K}^{\mathrm{a}}$ & $0.687^{* *}$ & $0.687^{* *}$ & $0.692^{* *}$ & $0.687^{* *}$ \\
\hline & & $p$ value & $<0.01$ & $<0.01$ & $<0.01$ & $<0.01$ \\
\hline
\end{tabular}

Negative (-) and positive (+) values indicate decreasing and increasing trends, respectively

**Correlation is significant at the 0.01 level (two-tailed); and

*Correlation is significant at the 0.05 level (two-tailed)

${ }^{a}$ Mann-Kendall test

Figure 6a reveals that the monthly river flow was comparable to the threshold at $10 \%$ of the time displaying reductions ranging from -8 (February) to -58 (July) between pre-damming and post-damming time-periods. However,
March showed a positive anomaly of $3 \%$. For the 25 th monthly percentiles (Fig. 6b), the alterations due to dam building were between $-2 \%$ (March and April) and $-26 \%$ (June and July). However, October, November and December 

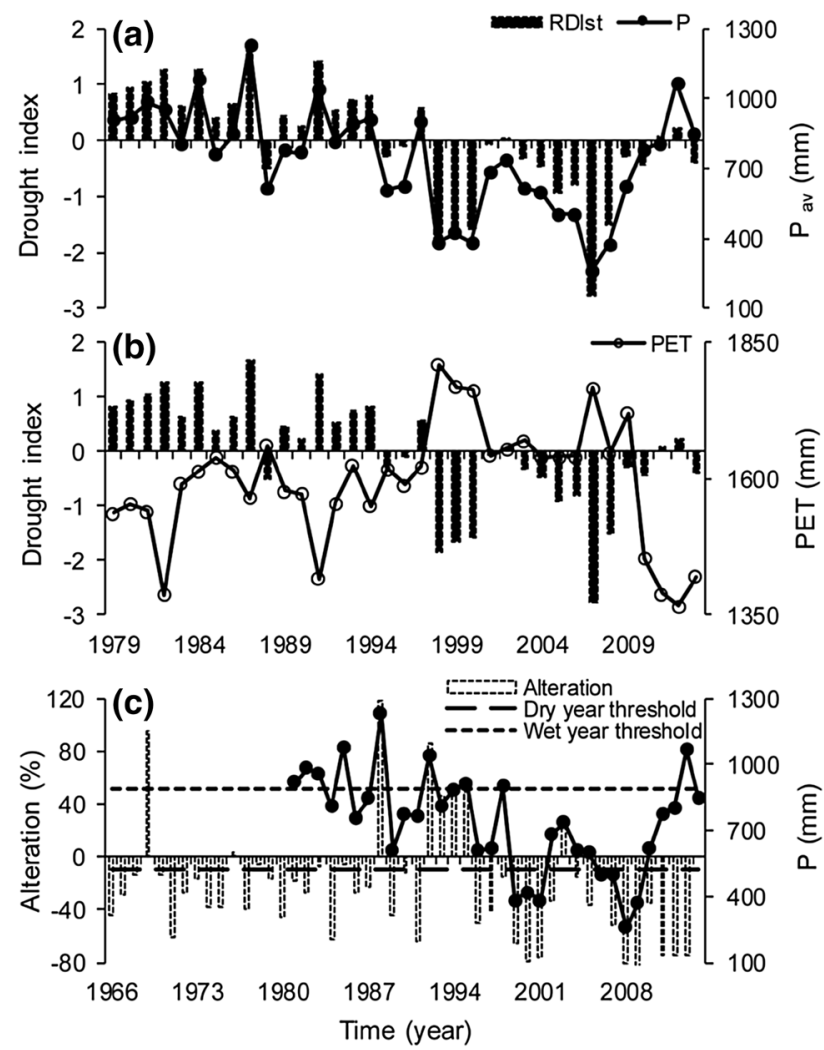

Fig. 3 Temporal variations in the standardised reconnaissance drought index $\left(\mathrm{RDI}_{\mathrm{st}}\right)$ coupled with the long-term average (a) precipitation $\left(P_{\mathrm{av}}\right)$; and $\mathbf{b}$ potential evapotranspiration (PET) and $\mathbf{c}$ the annual median anomaly for the period between 1966 and 2014 for both wet and dry years' thresholds coupled with long-term $P_{\mathrm{av}}$ for the Lower Zab River upper sub-basin over the period from 1979 to 2014

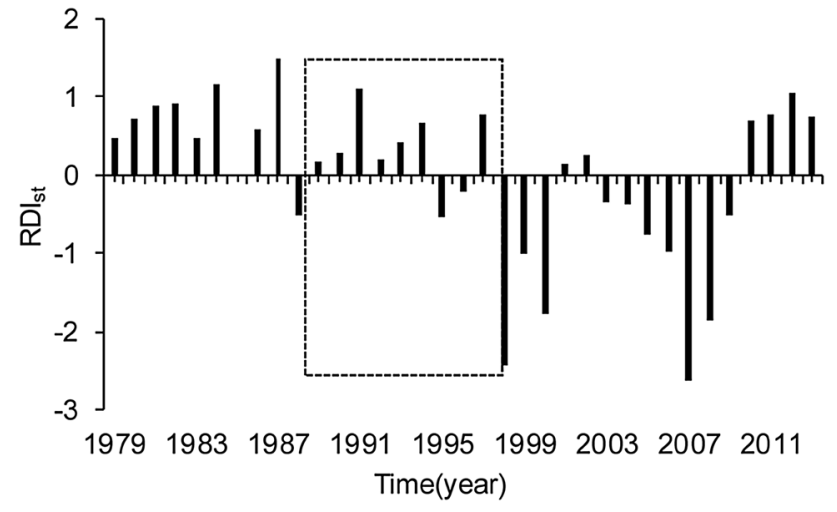

Fig. 4 Selected simulation period for the Reconnaissance Drought Index (RDI) applied for different climatic scenarios

showed positive shifts of 9,20 and $8 \%$ in this order. The anomalies linked with the monthly median flows (Fig. 6c) extended from between -2 (April) and $-28 \%$ (June) for the two time-periods, respectively. October, November, December, August and September experienced positive anomalies.
For the 75th percentile (Fig. 6d), the lowest anomaly was observed in April (-1\%), while the highest drop was recorded for July (-24\%). October, November, December, January, August and September experienced positive anomalies. The 90th monthly percentiles (Fig. 6e) were between - 1\% (February) and - 17 (March). Generally, between January and June, the alteration can be considered relatively small. In contrast, during the non-rainy months, there were considerable streamflow alterations that are due to the influence of both climate change and dam building, which decreased the basin water storage availability. Furthermore, Table 4 reveals that the 1-day to 7-day minimum flows remained almost the same, whereas there was a marked increase in the 30 -day minimum flow of about $38 \%$. The 1 -day to 90 -day maximum flows declined considerably. The corresponding declines ranged from -6 to $-37 \%$. This type of flow variation can be associated with the river regulation activities.

\section{Climate change impact}

The exposure of the prospective impacts of climate change on the hydro-climatic parameters is determined in the climate change and anthropogenic intervention impact analysis. The key result of climate change is that dry and wet annual inputs are categorised by minimum and maximum flows, respectively (Online Resource 8 ).

Figure $3 \mathrm{c}$ displays time series of the flowrate comparable to typical years with both dry and wet year thresholds. During the 1987 water year, a considerable elevation of the LZRB average precipitation of almost forty-four percentages more than the typical yearly extreme threshold has been recorded, which results in about $118 \%$ change in the streamflow with the equivalent yearly mean flow storage of $2.31 \times 10^{9} \mathrm{~m}^{3}$. However, a contrast was detected for the periods 1998-2001 and 2006-2008. These two hydrological years observed a considerable decrease in the basin average precipitation to almost 40 and $60 \%$ in this order. The decrease in the basin average precipitation leads to a considerable decrease in the river flow for the period between 1998 and 2001. The flow reduction for the hydrological years between 2006 and 2008 are about 52, 80 and, 83\%, and the average annual stream capacities of $0.76 \times 10^{9}, 0.29 \times 10^{9}$, and $0.31 \times 10^{9} \mathrm{~m}^{3}$, respectively. Furthermore, the hydrological years between 1991 and 2013 witnessed a streamflow alteration of about -75 and $-86 \%$ with storage capacities of about $0.31 \times 10^{9}$ and $1.24 \times 10^{9} \mathrm{~m}^{3}$ in this order. Findings proved that during the past few decades, climate change has negatively affected the LZRB water storage availability.

\section{Monthly percentiles}

Many temporal annual extreme values (1 day or 3, 7, 30, and 90 days) were estimated for the baseline and climate 

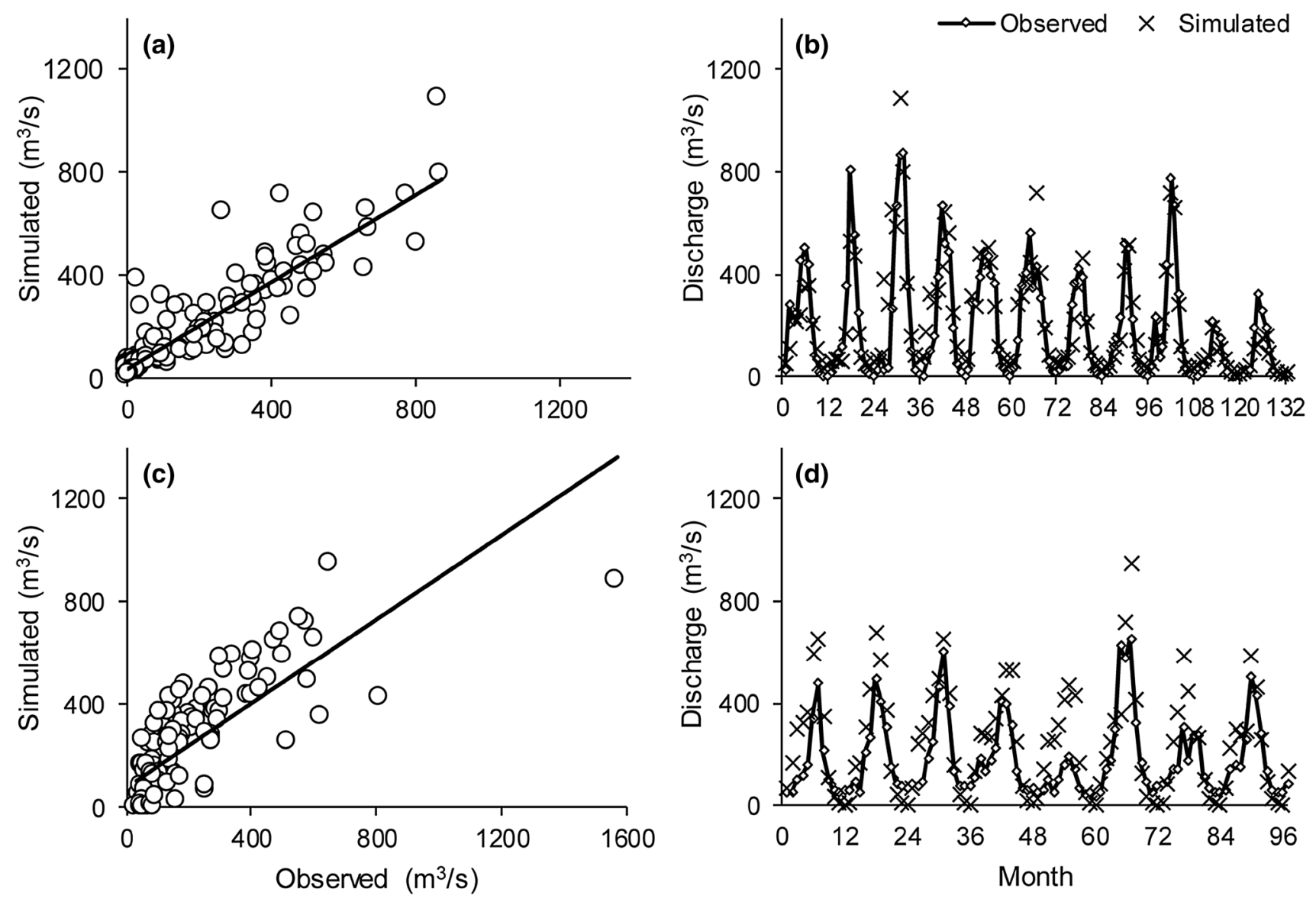

Fig. 5 Observed against simulated streamflow time series using the Hydrologiska Byråns Vattenbalansavdelning model for a and $\mathbf{b}$ calibration period (1988/1989-1999/2000); and c and d validation period (1979/1980-1986/1987), respectively

change scenarios. For group \#1, the hydrologic alteration stretched between minimum to maximum. Low to moderate levels of alteration were noticed in October, March, April, May and September (Table 5). A positive minimum level of alteration was detected in June for $0 \%$ reduction in precipitation coupled with $0,10,20$ and $30 \%$ increase in potential evapotranspiration, whereas the alteration was zero under the impact of $10 \%$ precipitation reduction linked with $0 \%$ potential evapotranspiration rise. A moderate alteration was observed in April for nearly all climatic scenario examples with alterations of about $-59,-60$ and $-62 \%$ for $20 \%$ precipitation reduction linked with 10,20 and 30\% potential evapotranspiration increase (Table 5).

For group \#2, the extreme minimum flows exhibited low anomalies. A low anomaly of about $-36 \%$ was linked to a 30-day minimum flow for the $\mathrm{F}_{12}$ scenario (Future 12; $20 \%$ decrease in precipitation linked with a $30 \%$ rise in potential evapotranspiration). Regarding the extreme maxima flows, group \#2 experienced modest to high alterations. Moderate to high alterations varied from -59 to $-73 \%$ associated with the 1-day maximum flow for the considered scenarios.
The 3-, 7-, and 30-day maxima flows were also associated with moderate to high alterations of -52 to $-68 \%,-46$ to $-64 \%$, and -42 to $-61 \%$, respectively, for all considered climatic scenarios. Low to moderate alterations of -30 and $-52 \%$ were linked to 90 days.

The temporal percentiles usually represent the potential changes in the basin hydrological characteristics, so that it can be considered as a vital statistical tool. In this study, five temporal percentiles $(10,25,50,75$ and 90th) that span the maximum streamflow thresholds were estimated for the baseline and the climate change scenarios. The estimation results are illustrated in Fig. 7 for the baseline and the two climate change scenario examples, $F_{9}(20 \%$ precipitation reduction integrated with $0 \%$ potential evapotranspiration rise) and $F_{13}(30 \%$ precipitation reduction integrated with $0 \%$ potential evapotranspiration rise). Figure 7a explains that the monthly flow was equivalent to or surpassed the threshold at $10 \%$ of the period exhibiting falls ranging between -42 and $-53 \%$ (May) to between -42 and $-54 \%$ (September) for $F_{9}$ and $F_{13}$, respectively. December, January, and February indicated positive anomalies ranging from 80 to $46 \%$ 

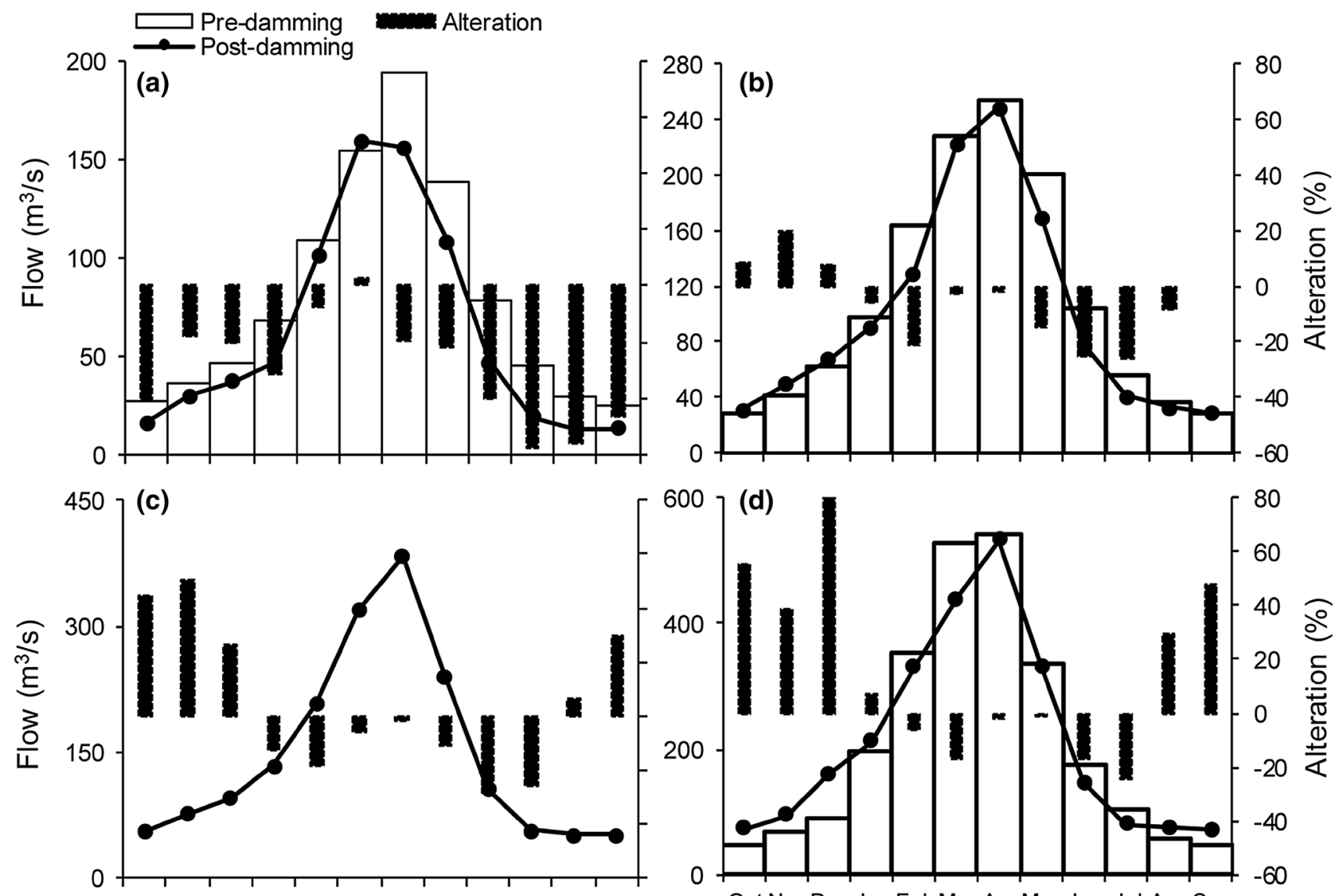

(d)
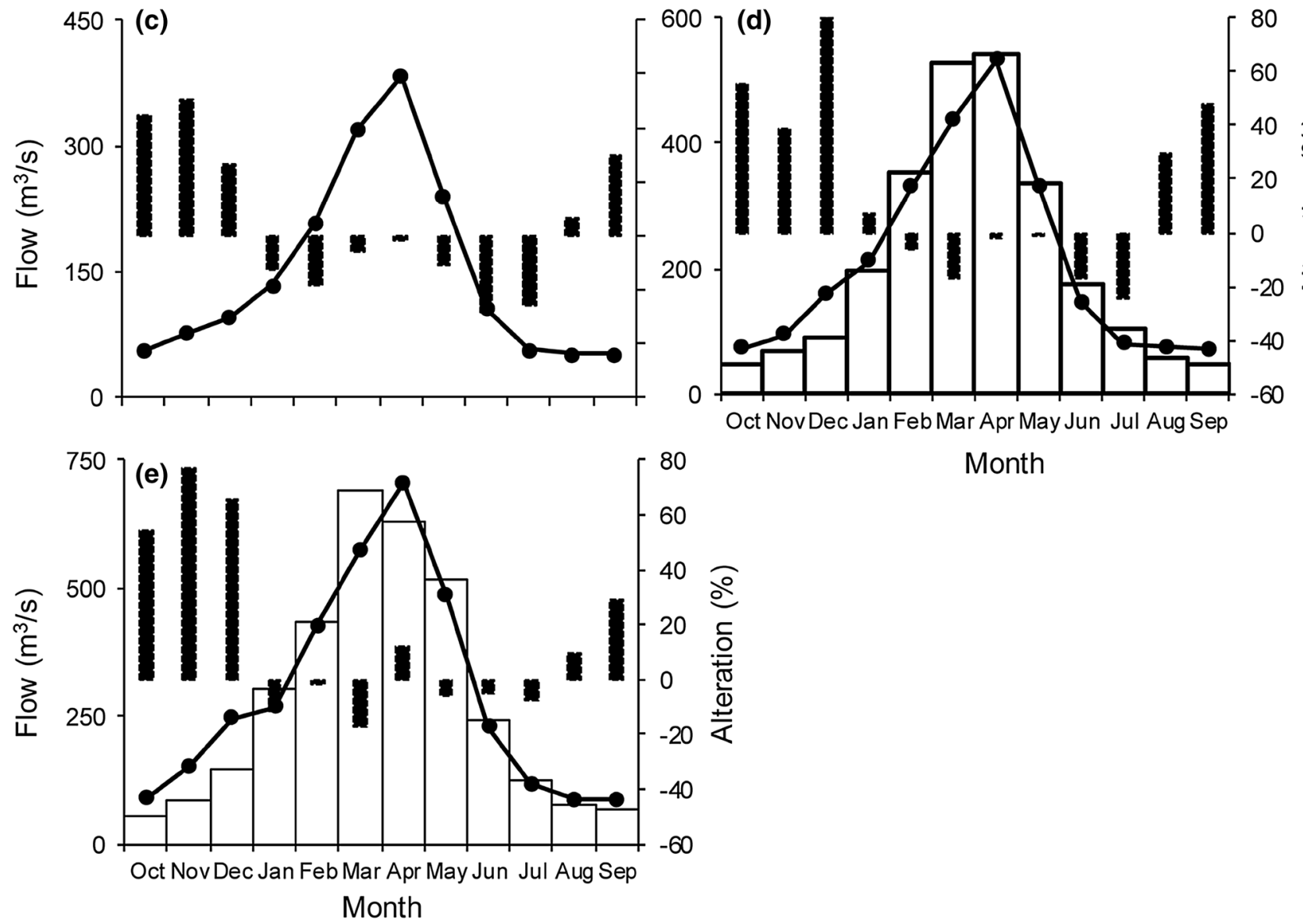

Month

Fig. 6 Comparison of monthly percentiles between pre-damming and post-damming periods coupled with the alteration ratio for the a 10th; $\mathbf{b}$ 25th; c 50th; d 75th; and e 90th percentiles

(December) and from 48 to $18 \%$ (January) for the two scenarios, respectively (Fig. 7a). For the 25th monthly percentiles, (Fig. 7b), the departures were between -43 and $-53 \%$ (October) to between -49 and $-60 \%$ (November). However, January, February, and June witnessed positive shifts of 16, 15 , and $25 \%$ in this order, based on $\mathrm{F}_{9}$ climatic scenario (Fig. 7b). The abnormalities related to the monthly median flows (Fig. 7c) extended from between -7 (November) and $-12 \%$ (February) to between -57 and $-64 \%$ (April) for the two considered climatic scenarios, respectively. January and July experienced positive anomalies. In contrast, in the 75th percentile (Fig. 7d), the lowest anomalies were observed in January $(-9 \%)$ and in October $(-19 \%)$ for $\mathrm{F}_{9}$ and $\mathrm{F}_{13}$ scenarios in this order, while the highest drops of between -58 
Table 4 Hydrologic alteration ratio for the annual median, minima, and maxima flow for the pre-damming and post-damming time periods

\begin{tabular}{llcc}
\hline Runoff $\left(\mathrm{m}^{3} / \mathrm{s}\right)$ & Pre-damming & Post-damming & Alteration $\%$ \\
\hline$n$ & $n$-day minima & & \\
$1-$ & 25.00 & 25.00 & 0 \\
$3-$ & 27.00 & 27.33 & 1 \\
$7-$ & 31.00 & 11 \\
$30-$ & 28.00 & 43.00 & 38 \\
$90-$ & 31.13 & 55.41 & 2 \\
$n$ & 54.32 & & \\
$1-$ & $n$-day maxima & -36 \\
$3-$ & 1279.00 & 820.00 & -22 \\
$7-$ & 1018.00 & 798.70 & -14 \\
$30-$ & 765.60 & 660.70 & -6 \\
$90-$ & 539.50 & 505.80 & -17 \\
BFI $^{\mathrm{a}}$ & 440.70 & 365.70 & 6 \\
\hline
\end{tabular}

${ }^{\mathrm{a}}$ Baseflow index

and $-65 \%$ were associated with April. The 90th monthly percentiles (Fig. 7e) were between -70 and $-75 \%$ (April), between -71 and -76 (May), and between -56 and $-64 \%$ (June) under the impact of 20 and $30 \%$ precipitation reduction integrated with no potential evapotranspiration increase, respectively. The results suggest that climate change will have an adverse overall impact on the basin in terms of water resource availability.

\section{Median streamflow}

The long-term median monthly streamflow of the baseline and some climatic scenario examples are illustrated in Fig. 8. For the baseline, the median flows varied from 43 (September) to $437 \mathrm{~m}^{3} / \mathrm{s}$ (April). In contrast, the median flows were reduced between 36, 35, 31, 29, 25 and $24 \mathrm{~m}^{3} / \mathrm{s}$ (September), and $267,259,226,219,187$ and $181 \mathrm{~m}^{3} / \mathrm{s}$ (March) as a result of 10,20 and $30 \%$ precipitation reduction linked with no $(0 \%)$ and $10 \%$ potential evapotranspiration rise, respectively (Fig. 8a). The noticeable alterations indicate dramatic signatures of the climate change pressures in the basin, which would reduce the basin water resource availability. Figure $8 \mathrm{~b}$ reveals the overall impact of climate change on the seasonal median flows within the LZRB.

Table 6 shows that the long-term median annual streamflow for the baseline and two climatic scenarios representing 10 and $20 \%$ reduction in the precipitation were estimated at 146,140 and $117 \mathrm{~m}^{3} / \mathrm{s}$ in this order, representing a departure between approximately -4 and $-20 \%$. The baseline median flows extended from 43 (August) to $437 \mathrm{~m}^{3} / \mathrm{s}$ (April), whereas the corresponding values were between 36 and $31 \mathrm{~m}^{3} / \mathrm{s}$ (September) and between 267 and $226 \mathrm{~m}^{3} / \mathrm{s}$
(March) for $F_{5}$ and $F_{9}$ climatic scenarios. The months March and April were related to substantial alterations fluctuating between -25 and $-57 \%$. Substantial alterations (mainly during the rainy seasons) illustrate considerable signs of the common impact of climate change, which noticeably would diminish the basin water resource availability. The 25 th percentile anomalies varied between -9 and $-23 \%$ (May) and between -42 and $-52 \%$ (November), revealing considerable deviation from the baseline condition. In relation to the 75th percentile, the departures were between -11 (February) and $-49 \%$ (April), and between -7 (August) and $-48 \%$ (May) for the two climate change scenario examples, respectively. The months March, April and May exhibited increases in the 75 th percentile fluctuating from -29 to $-57 \%$.

Furthermore, considering the climate change impacts on the isolated baseflow, Online Resource 9 shows as an example of the baseflow and the corresponding baseflow alteration sensitivity analysis under the impact of both potential evapotranspiration and rainfall. The baseflow is considerably sensitive to seasonal variations of precipitation values (Online Resource 9a). It can be considered less sensitive to potential evapotranspiration variations (Online Resource 9b). Accordingly, Online Resource 8c compares the longterm mean monthly baseflow alteration hydrographs for $F_{5}$, $F_{9}, F_{13}$, and $F_{17}$ climatic scenarios. The hydrograph rising limbs are adjacent to each other between October and February, and between June and September, which is compared with the baseflow ultimate alteration. A noticeable move was observed from April to July. Yet, the hydrographs hit the maximum positive alteration in May. The greatest alterations were approximately 54,30 and $7 \%$ for the $F_{5}, F_{9}$, and $F_{13}$ climatic scenarios, respectively. However, the peak point of the last scenario was $-15 \%$, which is considered as the minimum negative alteration.

Additionally, the population of the annual extreme magnitudes is summarised in the box and whisker plots in Online Resource 10, which evidently reveals that there is an extensive variability in the anticipated extreme conditions for each climate change scenario. The effect of climate change on the streamflow estimations mostly follows the impact on the annual extreme magnitudes. Thus, as precipitation and, hence, runoff decreases, the predicted annual minima and maxima decrease as well. Subsequently, a $10 \%$ precipitation reduction without any alteration in potential evapotranspiration increase ( $0 \%$ potential evapotranspiration) would mean that the 7-day minima magnitude would be reduced by as much as $23 \%$.

Moreover, the $C_{v}$, which is estimated as the SD of all daily flows separated by the average yearly flow, increases as the weather becomes dryer and hotter. The ratios of flow reliability to flow predictability had nearly constant values $(0.55-0.60)$. Data show that intervals for flood-free seasons increased from 
Table 5 Hydrologic alteration for the middle range of variability approach (RVA) category of the Lower Zab River Basin

\begin{tabular}{|c|c|c|c|c|c|c|c|c|c|c|c|c|}
\hline \multicolumn{13}{|c|}{ Degree of hydrologic alteration (\%) } \\
\hline Month & $F_{1}{ }^{\mathrm{a}}$ & $F_{2}^{\mathrm{b}}$ & $\mathrm{F}_{3}^{\mathrm{c}}$ & $F_{4}{ }^{\mathrm{d}}$ & $F_{5}{ }^{\mathrm{e}}$ & $F_{6}{ }^{\mathrm{f}}$ & $F_{7}{ }^{\mathrm{g}}$ & $F_{8}{ }^{\mathrm{h}}$ & $F_{9}^{\mathrm{i}}$ & $F_{10}{ }^{\mathrm{j}}$ & $F_{11}{ }^{\mathrm{k}}$ & $F_{12}^{1}$ \\
\hline \multicolumn{13}{|c|}{ Parameter group \#1 (comprising of monthly median discharge values) } \\
\hline Oct & $-17^{\mathrm{m}}$ & $-19^{\mathrm{m}}$ & $-22^{\mathrm{m}}$ & $-24^{\mathrm{m}}$ & $-30^{\mathrm{m}}$ & $-32^{\mathrm{m}}$ & $-34^{\mathrm{n}}$ & $-36^{\mathrm{n}}$ & $-43^{\mathrm{n}}$ & $-44^{\mathrm{n}}$ & $-46^{\mathrm{n}}$ & $-48^{\mathrm{n}}$ \\
\hline Nov & 36 & 32 & 27 & 23 & 14 & 10 & 6 & 3 & $-7^{\mathrm{m}}$ & $-11^{\mathrm{m}}$ & $-14^{\mathrm{m}}$ & $-16^{\mathrm{m}}$ \\
\hline Dec & 41 & 18 & 14 & 10 & 3 & $-1^{\mathrm{m}}$ & $-5^{\mathrm{m}}$ & $-8^{\mathrm{m}}$ & $-15^{\mathrm{m}}$ & $-19^{\mathrm{m}}$ & $-22^{\mathrm{m}}$ & $-25^{\mathrm{m}}$ \\
\hline Jan & 90 & 86 & 83 & 79 & 61 & $58^{\mathrm{n}}$ & 55 & 52 & 34 & 31 & 28 & 25 \\
\hline Feb & 48 & 47 & 44 & 41 & 29 & 26 & 23 & 20 & 8 & 6 & 3 & 1 \\
\hline Mar & $-14^{\mathrm{m}}$ & $-16^{\mathrm{m}}$ & $-18^{\mathrm{m}}$ & $-20^{\mathrm{m}}$ & $-25^{\mathrm{m}}$ & $-27^{\mathrm{m}}$ & $-30^{\mathrm{m}}$ & $-31^{\mathrm{m}}$ & $-37^{\mathrm{n}}$ & $-39^{n}$ & $-40^{\mathrm{n}}$ & $-42^{\mathrm{n}}$ \\
\hline Apr & $-41^{\mathrm{n}}$ & $-43^{\mathrm{n}}$ & $-45^{\mathrm{n}}$ & $-47^{\mathrm{n}}$ & $-49^{n}$ & $-51^{\mathrm{n}}$ & $-53^{\mathrm{n}}$ & $-54^{\mathrm{n}}$ & $-57^{\mathrm{n}}$ & $-59^{\mathrm{n}}$ & $-60^{\mathrm{n}}$ & $-62^{\mathrm{n}}$ \\
\hline May & $-17^{\mathrm{m}}$ & $-18^{\mathrm{m}}$ & $-20^{\mathrm{m}}$ & $-22^{\mathrm{m}}$ & $-27^{\mathrm{m}}$ & $-29^{\mathrm{m}}$ & $-31^{\mathrm{m}}$ & $-32^{\mathrm{m}}$ & $-38^{\mathrm{n}}$ & $-40^{\mathrm{n}}$ & $-41^{\mathrm{n}}$ & $-43^{n}$ \\
\hline Jun & 15 & 12 & 9 & 7 & 0 & $-3^{\mathrm{m}}$ & $-6^{\mathrm{m}}$ & $-8^{\mathrm{m}}$ & $-15^{\mathrm{m}}$ & $-18^{\mathrm{m}}$ & $-20^{\mathrm{m}}$ & $-22^{\mathrm{m}}$ \\
\hline Jul & 91 & 83 & 59 & 70 & 64 & 58 & 51 & 45 & 39 & 33 & $27^{\mathrm{m}}$ & $22^{\mathrm{m}}$ \\
\hline Aug & 44 & 38 & 19 & 28 & 24 & 19 & 14 & 10 & 5 & 0 & $-4^{\mathrm{m}}$ & $-8^{\mathrm{m}}$ \\
\hline Sep & $-11^{\mathrm{m}}$ & $-15^{\mathrm{m}}$ & $-22^{\mathrm{m}}$ & $-21^{\mathrm{m}}$ & $-24^{\mathrm{m}}$ & $-27^{\mathrm{m}}$ & $-30^{\mathrm{m}}$ & $-33^{\mathrm{m}}$ & $-36^{\mathrm{n}}$ & $-39^{n}$ & $-41^{\mathrm{n}}$ & $-44^{\mathrm{n}}$ \\
\hline \multicolumn{13}{|c|}{ Parameter group \#2 (magnitude and duration of annual extreme) } \\
\hline$n$ & \multicolumn{12}{|c|}{$n$-day minimum } \\
\hline 1 & $0^{\mathrm{m}}$ & $-5^{\mathrm{m}}$ & $-8^{\mathrm{m}}$ & $-11^{\mathrm{m}}$ & $-16^{\mathrm{m}}$ & $-19^{\mathrm{m}}$ & $-22^{\mathrm{m}}$ & $-24^{\mathrm{m}}$ & $-30^{\mathrm{m}}$ & $-32^{\mathrm{m}}$ & $-35^{\mathrm{n}}$ & $-37^{\mathrm{n}}$ \\
\hline 3 & $-1^{\mathrm{m}}$ & $-6^{\mathrm{m}}$ & $-9^{\mathrm{m}}$ & $-12^{\mathrm{m}}$ & $-17^{\mathrm{m}}$ & $-20^{\mathrm{m}}$ & $-22^{\mathrm{m}}$ & $-25^{\mathrm{m}}$ & $-30^{\mathrm{m}}$ & $-33^{\mathrm{m}}$ & $-35^{\mathrm{n}}$ & $-37^{\mathrm{n}}$ \\
\hline 7 & $-9^{\mathrm{m}}$ & $-13^{\mathrm{m}}$ & $-16^{\mathrm{m}}$ & $-19^{\mathrm{m}}$ & $-23^{\mathrm{m}}$ & $-26^{\mathrm{m}}$ & $-29^{\mathrm{m}}$ & $-31^{\mathrm{m}}$ & $-36^{\mathrm{n}}$ & $-38^{n}$ & $-40^{\mathrm{n}}$ & $-42^{\mathrm{n}}$ \\
\hline 30 & $-3^{\mathrm{m}}$ & $-6^{\mathrm{m}}$ & $-22^{\mathrm{m}}$ & $-11^{\mathrm{m}}$ & $-16^{\mathrm{m}}$ & $-19^{\mathrm{m}}$ & $-21^{\mathrm{m}}$ & $-24^{\mathrm{m}}$ & $-29^{\mathrm{m}}$ & $-31^{\mathrm{m}}$ & $-34^{\mathrm{n}}$ & $-36^{\mathrm{n}}$ \\
\hline 90 & $28^{\mathrm{m}}$ & $20^{\mathrm{m}}$ & $15^{\mathrm{m}}$ & $12^{\mathrm{m}}$ & $5^{\mathrm{m}}$ & $2^{\mathrm{m}}$ & $-1^{\mathrm{m}}$ & $-4^{\mathrm{m}}$ & $-12^{\mathrm{m}}$ & $-15^{\mathrm{m}}$ & $-18^{\mathrm{m}}$ & $-20^{\mathrm{m}}$ \\
\hline$n$ & \multicolumn{12}{|c|}{$n$-day maximum } \\
\hline 1 & $-59^{\mathrm{n}}$ & $-60^{\mathrm{n}}$ & $-61^{\mathrm{n}}$ & $-62^{\mathrm{n}}$ & $-65^{\mathrm{n}}$ & $-66^{\mathrm{n}}$ & $-67^{\mathrm{n}}$ & $-68^{\circ}$ & $-70^{\circ}$ & $-71^{\circ}$ & $-72^{\circ}$ & $-73^{\circ}$ \\
\hline 3 & $-52^{\mathrm{n}}$ & $-53^{\mathrm{n}}$ & $-54^{\mathrm{n}}$ & $-56^{\mathrm{n}}$ & $-58^{\mathrm{n}}$ & $-60^{\mathrm{n}}$ & $-61^{\mathrm{n}}$ & $-62^{\mathrm{n}}$ & $-65^{\mathrm{n}}$ & $-66^{\mathrm{n}}$ & $-67^{\mathrm{n}}$ & $-68^{\circ}$ \\
\hline 7 & $-46^{\mathrm{n}}$ & $-48^{\mathrm{n}}$ & $-49^{\mathrm{n}}$ & $-50^{\mathrm{n}}$ & $-54^{\mathrm{n}}$ & $-55^{\mathrm{n}}$ & $-56^{\mathrm{n}}$ & $-57^{\mathrm{n}}$ & $-61^{\mathrm{n}}$ & $-62^{\mathrm{n}}$ & $-63^{\mathrm{n}}$ & $-64^{n}$ \\
\hline 30 & $-42^{\mathrm{n}}$ & $-44^{\mathrm{n}}$ & $-45^{\mathrm{n}}$ & $-47^{\mathrm{n}}$ & $-50^{\mathrm{n}}$ & $-51^{\mathrm{n}}$ & $-53^{\mathrm{n}}$ & $-54^{\mathrm{n}}$ & $-58^{\mathrm{n}}$ & $-59^{n}$ & $-60^{\mathrm{n}}$ & $-61^{\mathrm{n}}$ \\
\hline 90 & $-30^{\mathrm{m}}$ & $-30^{\mathrm{m}}$ & $-32^{\mathrm{m}}$ & $-34^{\mathrm{n}}$ & $-38^{n}$ & $-40^{\mathrm{n}}$ & $-42^{\mathrm{n}}$ & $-43^{\mathrm{n}}$ & $-48^{\mathrm{n}}$ & $-49^{n}$ & $-51^{\mathrm{n}}$ & $-52^{\mathrm{n}}$ \\
\hline $\mathrm{BFI}^{\mathrm{p}}$ & $8^{\mathrm{m}}$ & $6^{\mathrm{m}}$ & $6^{\mathrm{m}}$ & $6^{\mathrm{m}}$ & $7^{\mathrm{m}}$ & $7^{\mathrm{m}}$ & $7^{\mathrm{m}}$ & $7^{\mathrm{m}}$ & $7^{\mathrm{m}}$ & $7^{\mathrm{m}}$ & $7^{\mathrm{m}}$ & $7^{\mathrm{m}}$ \\
\hline
\end{tabular}

Degree of alteration

a, b, c, and d $(0 \%$ reduction in precipitation $(P)$ linked with $0,10,20$ and $30 \%$ increase in potential evapotranspiration (PET), respectively);

e, f, g, and h (10\% reduction in P linked with 0, 10, 20 and 30\% increase in PET, respectively); and

$\mathrm{i}, \mathrm{j}, \mathrm{k}, \mathrm{l}(20 \%$ reduction in $\mathrm{P}$ linked with $0,10,20$, and $30 \%$ increase in PET, respectively)

${ }^{m}$ Slight;

${ }^{\mathrm{n}}$ Modest;

${ }^{\circ} \mathrm{High}$; and

${ }^{\mathrm{p}}$ Baseflow index
145 to 307 days for the first and the last climatic scenarios, respectively. Online Resource 11 reveals that a significantly $(p<0.05)$ low count has been calculated during December, which means that there is a significant difference between the baseline (1988 - 2000) and the impacted period, while high values were recorded during the rainy months.

\section{Conclusions and recommendation}

A generic methodology has been proposed that would enhance strategies for climate change adaptation by water resource managers. The following conclusions have been 

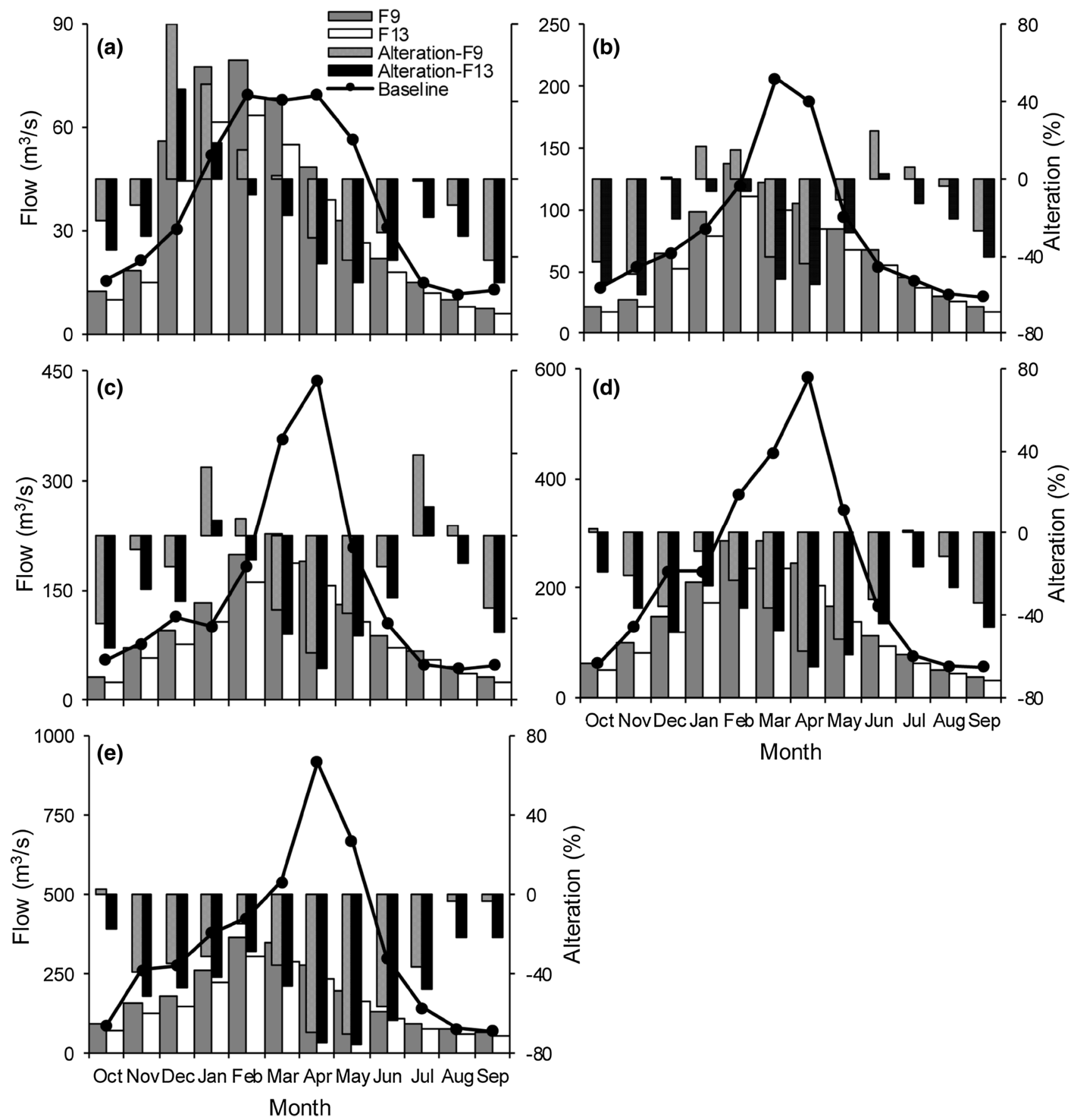

Fig. 7 Comparison of monthly percentiles between the baseline and two future climate change scenario examples, which are $F_{9}$ and $F_{13}$ [20 and 30\% reduction in precipitation $(P)$, respectively, linked with

$0 \%$ increase in potential evapotranspiration (PET)] coupled with the alteration ratio for the a 10th; b 25th; c 50th; d 75th; and e 90th percentiles

drawn:

The RDI index is the most suitable meteorological drought index for arid and semi-arid climates. The case study region already experienced increases in drought periods due to precipitation reductions (after 1999). Non-uniform cyclical characteristics of wet and dry durations were witnessed. Seasonal droughts were recorded over the years

$1998 / 1999,1999 / 2000$, and 2000/2001. The year 2007/2008 witnessed a severe drought, whereas the year $1987 / 1988$ was characterised by a significant $(p<0.05)$ increase in the basin average precipitation. Almost $80 \%$ of the streamflow reduction was observed for the years 1998-2002 and 2006-2008 as a consequence of a sharp drop in the basin average precipitation. The separated base flow is considerably sensitive to 


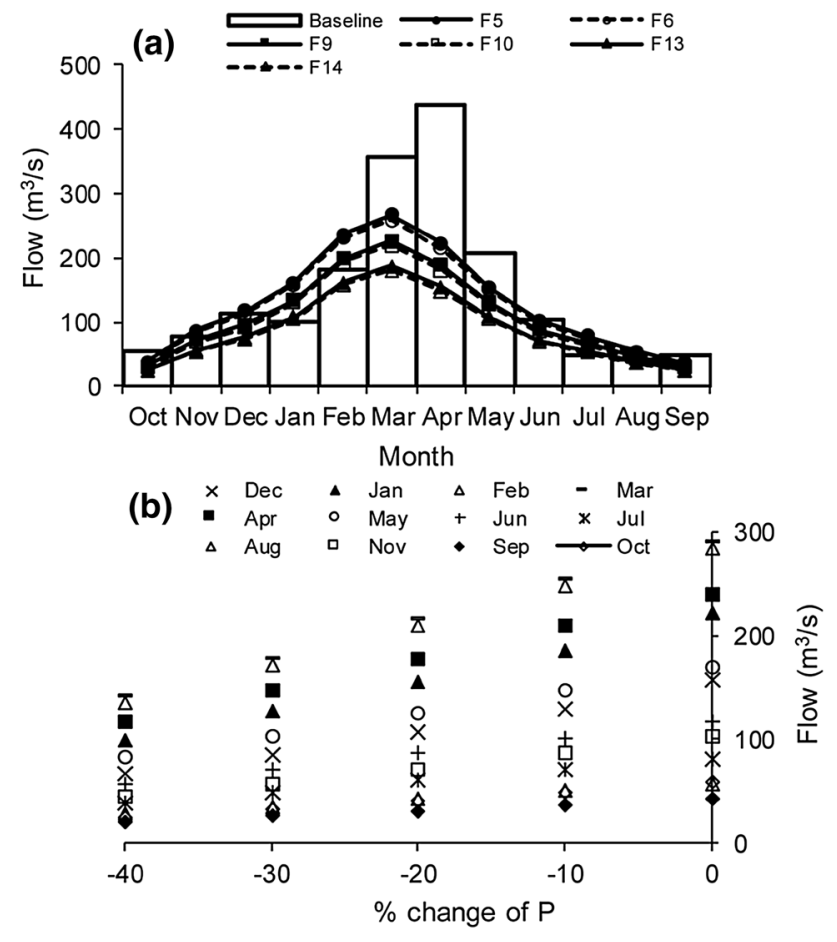

Fig. 8 a Comparison of the long-term monthly median flows between the baseline and some climate change scenario examples, and $\mathbf{b}$ anticipated alteration in the long-term mean monthly flow, in the Lower Zab River, due to a reduction in precipitation $(P)$. Note: future, $F_{5}$ and $F_{6}(10 \%$ reduction in $P$ linked with 0 and $10 \%$ increase in potential evapotranspiration (PET), respectively), $F_{9}$ and $F_{10}$ (20\% reduction in $\mathrm{P}$ linked with 0 and $10 \%$ increase in PET, respectively), and $F_{13}$ and $F_{14}$ (30\% reduction in $\mathrm{P}$ linked with 0 and $10 \%$ increase in PET, respectively)

the seasonal variations of precipitation values, whereas, it is less sensitive to the potential evapotranspiration variations.

For the 10th monthly percentile, the anomalies exhibiting falls ranged between -8 (February) and $-58 \%$ (July) due to dam construction (i.e. direct human-induced impact) to between -42 and $-54 \%$ (September) due to climate change, respectively. For the 25th monthly percentiles, the departures were between -2 (April) and - 53\% (June) due to human-induced impact to between -43 (October) and $-60 \%$ (November) due to climate change effects. However, the abnormalities related to the monthly median flows extended from between -2 (April) and $-24 \%$ (July) due to humans to between -7 (November) and $-64 \%$ (April) due to climate change, respectively. For the 75 th percentile, the lowest anomalies were observed in April $(-1 \%)$ and in January $(-9 \%)$, while the highest drops of between -24 (July) and $-65 \%$ (April) as a result of humans and climate change in this order. The 90th monthly percentiles were between -1 (February) and $-17 \%$ (March), and between -56 (May) and $-64 \%$ (June) under the impact of anthropogenic activities, and 20 and $30 \%$ precipitation reduction, respectively. Accordingly, the simulation results proved that climate change would have a more extensive and solid impact on the streamflow hydrological characteristics than human-induced activities (i.e. building of dams).

Furthermore, the effect of climate change on the streamflow estimations generally mirrors the effect on the annual extreme magnitudes. For example, a $10 \%$ precipitation reduction would result in $23 \%$ reduction in the 7 -day minima magnitude. The duration of the flood-free season would increase due to climate change impacts. The considerable variation during the dry months caused by the impact of climate change and anthropogenic intervention in the region would lead to a decrease in the basin water storage obtainability.

It is highly recommended for this study to be undertaken again taking also into consideration the long-term accumulation of anthropogenic intervention such as land use and land cover, agricultural practices as well as urbanisation that the basin experienced over the past 35 years. Moreover, the presented approach should also be verified for other unrelated case studies. 
Table 6 Comparison of some monthly parameters between the baseline and two of the selected climate change scenarios

\begin{tabular}{|c|c|c|c|c|c|c|c|c|c|c|c|c|}
\hline${ }^{a} P_{e}$ & Oct & Nov & Dec & Jan & Feb & Mar & Apr & May & Jun & Jul & Aug & Sep \\
\hline \multicolumn{13}{|c|}{ Baseline } \\
\hline $1^{\mathrm{b}}$ & 15 & 20 & 30 & 48 & 48 & 48 & 48 & 48 & 28 & 14 & 11 & 13 \\
\hline $2^{c}$ & 38 & 62 & 66 & 90 & 122 & 291 & 219 & 112 & 61 & 46 & 33 & 32 \\
\hline $3^{d}$ & 54 & 77 & 113 & 100 & 183 & 357 & 437 & 209 & 104 & 48 & 43 & 48 \\
\hline $4^{\mathrm{e}}$ & 59 & 95 & 221 & 225 & 360 & 427 & 568 & 317 & 146 & 70 & 55 & 53 \\
\hline $5^{\mathrm{f}}$ & 97 & 283 & 286 & 397 & 426 & 549 & 1083 & 781 & 348 & 160 & 79 & 72 \\
\hline \multicolumn{13}{|l|}{$F_{5}{ }^{\mathrm{g}}$} \\
\hline $1^{\mathrm{b}}$ & 10 & 21 & 68 & 90 & 94 & 72 & 49 & 33 & 22 & 15 & 10 & 8 \\
\hline $2^{\mathrm{c}}$ & 26 & 36 & 81 & 135 & 202 & 187 & 151 & 102 & 91 & 61 & 41 & 28 \\
\hline $3^{d}$ & 38 & 87 & 117 & 161 & 236 & 267 & 223 & 153 & 103 & 79 & 53 & 36 \\
\hline $4^{e}$ & 72 & 122 & 161 & 240 & 322 & 305 & 287 & 193 & 130 & 89 & 60 & 42 \\
\hline $5^{\mathrm{f}}$ & 120 & 196 & 230 & 312 & 448 & 415 & 349 & 248 & 167 & 112 & 100 & 100 \\
\hline \multicolumn{13}{|c|}{ Alteration (\%) } \\
\hline $2^{c}$ & $-30^{\mathrm{i}}$ & $-42^{j}$ & 22 & 50 & 66 & $-36^{\mathrm{j}}$ & $-31^{\mathrm{i}}$ & $-9^{\mathrm{i}}$ & 51 & 33 & 24 & $-12^{\mathrm{i}}$ \\
\hline $3^{d}$ & $-30^{\mathrm{i}}$ & 14 & 3 & 61 & 29 & $-25^{\mathrm{i}}$ & $-49^{j}$ & $-27^{\mathrm{i}}$ & 0 & 64 & 24 & $-24^{\mathrm{i}}$ \\
\hline $4^{e}$ & 22 & 29 & $-27^{j}$ & 7 & $-11^{\mathrm{i}}$ & $-29^{\mathrm{i}}$ & $-49^{j}$ & $-39^{j}$ & $-11^{\mathrm{i}}$ & 27 & 8 & -20 \\
\hline \multicolumn{13}{|l|}{$F_{9}{ }^{\mathrm{h}}$} \\
\hline $1^{\mathrm{b}}$ & 8 & 18 & 56 & 74 & 78 & 59 & 41 & 27 & 18 & 12 & 8 & 7 \\
\hline $2^{c}$ & 22 & 30 & 66 & 112 & 169 & 157 & 127 & 86 & 77 & 52 & 35 & 24 \\
\hline $3^{d}$ & 31 & 71 & 96 & 134 & 198 & 226 & 189 & 130 & 88 & 67 & 45 & 31 \\
\hline $4^{e}$ & 59 & 101 & 134 & 201 & 273 & 259 & 245 & 166 & 112 & 76 & 51 & 36 \\
\hline $5^{\mathrm{f}}$ & 99 & 163 & 194 & 276 & 382 & 355 & 299 & 212 & 143 & 96 & 82 & 82 \\
\hline \multicolumn{13}{|c|}{ Alteration (\%) } \\
\hline $2^{c}$ & $-42^{\mathrm{j}}$ & $-52^{j}$ & 0 & 25 & 39 & $-46^{\mathrm{j}}$ & $-42^{j}$ & $-23^{\mathrm{i}}$ & 28 & 13 & 6 & $-25^{\mathrm{i}}$ \\
\hline $3^{d}$ & $-43^{\mathrm{j}}$ & $-7^{\mathrm{i}}$ & $-15^{\mathrm{i}}$ & 34 & 8 & $-37^{\mathrm{j}}$ & $-57^{j}$ & $-38^{j}$ & $-15^{\mathrm{i}}$ & 39 & 5 & $-36^{\mathrm{j}}$ \\
\hline $4^{e}$ & 0 & 6 & $-39^{j}$ & $-11^{\mathrm{i}}$ & $-24^{\mathrm{i}}$ & $-39^{j}$ & $-57^{\mathrm{j}}$ & $-48^{j}$ & $-23^{\mathrm{i}}$ & 9 & $-7^{\mathrm{i}}$ & $-32^{\mathrm{i}}$ \\
\hline
\end{tabular}

${ }^{\text {aPercentile }}$

${ }^{\mathrm{b}}$ Minimum

c25th Percentile

${ }^{\mathrm{d}}$ Median

e 75th Percentile

${ }^{\mathrm{f}}$ Maximum

$\mathrm{g}, \mathrm{h}(10$ and $20 \%$ reduction in precipitation $(\mathrm{P})$, respectively, linked with $0 \%$ increase in potential evapotranspiration (PET));

${ }^{\mathrm{i}}$ Slight

${ }^{\mathrm{j}}$ Modest
Acknowledgements The work has been sponsored by the Government of Iraq via Babylon University as part of a $\mathrm{PhD}$ scholarship for the lead author.

Open Access This article is distributed under the terms of the Creative Commons Attribution 4.0 International License (http://creativeco mmons.org/licenses/by/4.0/), which permits unrestricted use, distribution, and reproduction in any medium, provided you give appropriate credit to the original author(s) and the source, provide a link to the Creative Commons license, and indicate if changes were made.

\section{References}

Agha Kouchak A, Farahmand A, Melton FS, Teixeira J, Anderson MC, Wardlow BD, Hain CR (2015) Remote sensing of drought:
Progress, challenges, and opportunities. Rev Geophys 53(2):452480. https://doi.org/10.1002/2014RG000456

Al-Faraj F, Scholz M (2014) Impact of upstream anthropogenic river regulation on downstream water availability in transboundary river watersheds. Int J Water Resour D 31(1):28-49. https://doi. org/10.1080/07900627.2014.92439531

Allen RG, Pereira LS, Raes D, Smith M (1998) Crop evapotranspiration: guidelines for computing crop water requirements. Food and Agriculture Organization (FAO) irrigation and drainage paper 56, first ed, Rome

Bergström S (1976) Development and application of a conceptual runoff model for Scandinavian catchments. Swedish Meteorological and Hydrological Institute (SMHI) Report RHO 7, Norrköping, p 134

Bergström S (1992) The HBV model: its structure and applications. Swedish Meteorological and Hydrological Institute (SMHI) Report RHO 4, Norrköping, p 35 
Chen J, Brissette FP, Leconte R (2011) Uncertainty of downscaling method in quantifying the impact of climate change on hydrology. J Hydrol 401(3-4):190-202. https://doi.org/10.1016/j.jhydr ol.2011.02.020

Cook BI, Smerdon JE, Seager R, Coats S (2014) Global warming and 21st century drying. Clim Dyn 43(9-10):2607-2627. https://doi. org/10.1007/s00382-014-2075-y

Doll P, Zhang J (2010) Impact of climate change on freshwater ecosystems: a global-scale analysis of ecologically relevant river flow alterations. Hydrol Earth Syst Sci 14(5):783-799. https://doi. org/10.5194/hess-14-783-2010

Duan W, Guo S, Wang J, Liu D (2016) Impact of cascaded reservoirs group on flow regime in the middle and lower reaches of the Yangtze River. Water 8(6):218. https://doi.org/10.3390/w8060218

Fadhil MA (2011) Drought mapping using Geoinformation technology for some sites in the Iraqi Kurdistan region. Int J Digit Earth 4(3):239-257. https://doi.org/10.1080/17538947.2010.489971

FAO (2012) Food and Agriculture Organization of the UN. Adaptation to climate change in semi-arid environments. Experience and lessons from Mozambique. Environment and Natural Resources Management Series. Rome. pp. 1-83. Retrieved from http://www.fao.org/docrep/015/i2581e/i2581e00.pdf. Accessed 9 May 2018

Foehn A, García Hernández J, Roquier B, Paredes Arquiola J (2016) RS MINERVE-User's manual v2.6. RS MINERVE Group, Switzerland

GADM (2012) Global administrative areas database. Retrieved from http://www.gadm.org. Accessed 9 May 2018

Gao B, Yang D, Yang H (2013) Impact of the Three Gorges Dam on flow regime in the middle and lower Yangtze River. Quat Int 304:43-50

Giannikopoulou AS, Kampragkou E, Gad FK, Kartalidis A, Assimacopoulos D (2014) Drought characterisation in Cyclades complex, Greece. Eur Water 47:31-43

Gibson CA, Meyer JL, Poff NL, Hay LE, Georgakakos A (2005) Flow regime alterations under changing climate in two river basins: Implications for freshwater ecosystems. River Res App 21(8):849-864. https://doi.org/10.1002/rra.855

GLCF (2015) Global and Land Cover Facility. Retrieved from http:// www.landcover.org/data/srtm. Accessed 9 May 2018

Guo Y, Li Z, Amo-Boateng M, Deng P, Huang P (2014) Quantitative assessment of the impact of climate variability and human activities on runoff changes for the upper reaches of Weihe River. Stoch Env Res Risk A 28(2):333-346. https://doi.org/10.1007/ s00477-013-0752-8

Heim Jr RR (2002) A review of twenty-century drought indices used in the United State. Bull Amer Meteor Soc 83(8):1149-1165. https:// doi.org/10.1175/1520-0477(2002)083<1149:AROTDI>2.3.CO;2

Hoerling MP, Eischeid JK, Quan XW, Diaz HF, Webb RS, Dole RM, Esterling DR (2012) Is a transition to semi-permanent drought conditions imminent in the U.S. Great Plains? J Clim 25(24):8380-8386. https://doi.org/10.1175/JCLI-D-12-00449.1

HydroOffice (2015) Retrieved from https://hydrooffice.org/Downl oads?Items=Software. Accessed 9 May 2018

Information Technology Services (ITS) (2016) IBM SPSS statistics 23 Part 3: Regression analysis. Winter 2016, Version 1

IPCC (2014) Intergovernmental Panel on Climate Change. Climate Change 2014: impacts, adaptation, and vulnerability http://www. ipcc.ch/report/ar5/wg2. Accessed 15 May 2015

Jiang L, Ban X, Wang X, Cai X (2014) Assessment of hydrologic alterations caused by the Three Gorges Dam in the middle and lower reaches of Yangtze River, China. Water 6(5):1419-1434. https://doi.org/10.3390/w6051419

Kim BS, Kim BK, Kwon HH (2011) Assessment of the impact of climate change on the flow regime of the Han River basin using indicators of hydrologic alteration. Hydrol Process 25(5):691704. https://doi.org/10.1002/hyp.7856

Lee A, Cho S, Kang DK, Kim S (2014) Analysis of the effect of climate change on the Nakdong river stream flow using indicators of hydrological alteration. J Hydro-environ Res 8(3):234-247. https ://doi.org/10.1016/j.jher.2013.09.003

Masih I, Uhlenbrook S, Ahmad MD, Maskey S (2010) Regionalization of a conceptual rainfall runoff model based on similarity of the flow duration curve: a case study from Karkheh River Basin, Iran. J Hydrol 391(1-2):188-201. https://doi.org/10.1016/j.jhydr ol.2010.07.018

Mittal N, Mishra A, Singh R, Bhave AG, van der Valk M (2014) Flow regime alteration due to anthropogenic and climatic changes in the Kangsabati River, India. Ecohydrol Hydrobiol 14(3):182-191. https://doi.org/10.1016/j.ecohyd.2014.06.002

Mittal N, Bhave AG, Mishra A, Singh R (2016) Impact of human intervention and climate change on natural flow regime. Water Resour Manage 30(2):685-699. https://doi.org/10.1007/s1126 9-015-1185-6

Mohammed R, Scholz M (2016) Impact of climate variability and streamflow alteration on groundwater contribution to the base flow of the Lower Zab River (Iran and Iraq). Environ Earth Sci 75(21):1392. https://doi.org/10.1007/s12665-016-6205-1

Mohammed R, Scholz M (2017a) Impact of evapotranspiration formulations at various elevations on the reconnaissance drought index. Water Resour Manage 31(1):531-548. https://doi.org/10.1007/ s11269-016-1546-9

Mohammed R, Scholz M (2017b) The reconnaissance drought index: a method for detecting regional arid climatic variability and potential drought risk. J Arid Environ 144:181-191. https://doi. org/10.1016/j.jaridenv.2017.03.014

Mohammed R, Scholz M (2017c) Adaptation strategy to mitigate the impact of climate change on water resources in arid and semi-arid regions: a case study. Water Resour Manage, 1-17. https://doi. org/10.1007/s11269-017-1685-7

Mohammed R, Scholz M, Zounemat-Kermani M (2017) Temporal hydrologic alterations coupled with climate variability and drought for transboundary river basins. Water Resour Manage 31:1489-1502. https://doi.org/10.1007/s11269-017-1590-0

Mohammed R, Scholz M, Nanekely MA, Mokhtari Y (2018) Assessment of models predicting anthropogenic interventions and climate variability on surface runoff of the Lower Zab River. Stoch Env Res Risk A 32(1):223-240. https://doi.org/10.1007/s0047 7-016-1375-7

NOAA (2009) National Oceanic and Atmospheric Administration Climate of Iraq https://www.ncdc.noaa.gov/oa/climate/afghan/ iraq-narrative.html. Accessed 4 Nov 2015

Reis J, Culver TB, Block PJ, McCartney MP (2016) Evaluating the impact and uncertainty of reservoir operation for malaria control as the climate changes in Ethiopia. Clim Chang 136(3-4):601614. https://doi.org/10.1007/s10584-016-1639-8

Richter B, Baumgartner J, Wigington R, Braun D (1997) How much water does a river need? Freshwater boil 37(1):231-249

Richter BD, Baumgartner JV, Braun DP, Powell J (1998) A spatial assessment of hydrologic alteration within a river network. Requl River 14(4):329-340. https://doi.org/10.1002/(SICI)10991646(199807/08)14:4<329::AID-RRR505>3.0.CO;2-E

Robaa SM, AL-Barazanji ZJ (2013) Trends of annual mean surface air temperature over Iraq. Nat Sci 11(12):138-145

RS MINERVE 2.5 software (2016) Download [Online]. https://www. crealp.ch/down/rsm/install2/archives.html. Accessed 15 June 2016

Saeedrashed Y, Guven A (2013) Estimation of geomorphological parameters of Lower Zab River-Basin by using GIS-based remotely sensed image. Water Resour Manage 27(2017):209-219. https://doi.org/10.1007/s11269-012-0179-x 
Sheffield J, Wood EF, Roderick ML (2012) Little change in global drought over the past 60 years. Nature 491(7424):435-438. https ://doi.org/10.1038/nature11575

Soundharajan BS, Adeloye AJ, Remesan R (2016) Evaluating the variability in surface water reservoir planning characteristics during climate change impacts assessment. J Hydrol 538:629-639. https ://doi.org/10.1016/j.jhydrol.2016.04.051

Stagl JC, Hattermann FF (2016) Impacts of climate change on riverine ecosystems: Alterations of ecologically relevant flow dynamics in the Danube River and its major tributaries. Water 8(12):566. https ://doi.org/10.3390/w8120566

Sun T, Feng ML (2013) Multistage analysis of hydrologic alterations in the Yellow River, China. River Res Appl 29(8):991-1003. https ://doi.org/10.1002/rra.2586

The Nature Conservancy (2009) Indicators of hydrologic alteration version 7.1 user's manual. The Nature Conservancy, June, p 76

Tigkas D, Vangelis H, Tsakiris G (2012) Drought and climatic change impact on streamflow in small watersheds. Sci Total Environ 440:33-41. https://doi.org/10.1016/j.scitotenv.2012.08.035

Tigkas D, Vangelis H, Tsakiris G (2015) DrinC: a software for drought analysis based on drought indices. Earth Sci Inform 8(3):697-709. https://doi.org/10.1007/s12145-014-0178-y

UNESCO (2014) United Nations Educational, Scientific and Cultural Organization. Integrated Drought Risk Management-DRM National Framework for Iraq. An analysis report. Retrieved from http://unesdoc.unesco.org/images/0022/002283/22834 3E.pdf UN-ESCWA and BGR (United Nations Economic and
Social Commission for Western Asia; Bundesanstalt für Geowissenschaften und Rohstoffe) (2013) Inventory of Shared Water Resources in Western Asia, Beirut

Vicente-Serrano SM, Begueria S, Lopez-Moreno JI (2010) A Multiscalar drought index sensitive to global warming: the standardized precipitation evapotranspiration index. J Clim 23(7):1696-1718. https://doi.org/10.1175/2009JCLI2909.1

Vicente-Serrano SM, Lopez-Moreno JI, Beguería S, Lorenzo-Lacruz J, Sanchez-Lorenzo A, García-Ruiz JM, Azorin-Molina C, Morán-Tejeda E, Revuelto J, Trigo R, Coelho F (2014) Evidence of increasing drought severity caused by temperature rise in southern Europe. Environ Res Lett 9(4):044001. https://doi. org/10.1088/1748-9326/9/4/044001

Vicente-Serrano SM, Schrier G, Begueria S, Azorin-Molina C, LopezMoreno J (2015) Contribution of precipitation and reference evapotranspiration to drought indices under different climates. J Hydrol 526:42-54. https://doi.org/10.1016/j.jhydrol.2014.11.025

Wang Y, Rhoads BL, Wang D (2016) Assessment of the flow regime alterations in the middle reach of the Yangtze River associated with dam construction: potential ecological implications. Hydrol Process 30(21):3949-3966. https://doi.org/10.1002/hyp.10921

Yan Y, Yang Z, Liu Q, Sun T (2010) Assessing effects of dam operation on flow regimes in the lower Yellow River. Proc Environ Sci 2:507-516. https://doi.org/10.1016/j.proenv.2010.10.055 